CAMBRIAN STRATA OF NORTHEASTERN IOWA

by

WALTER C. SCHULDT 


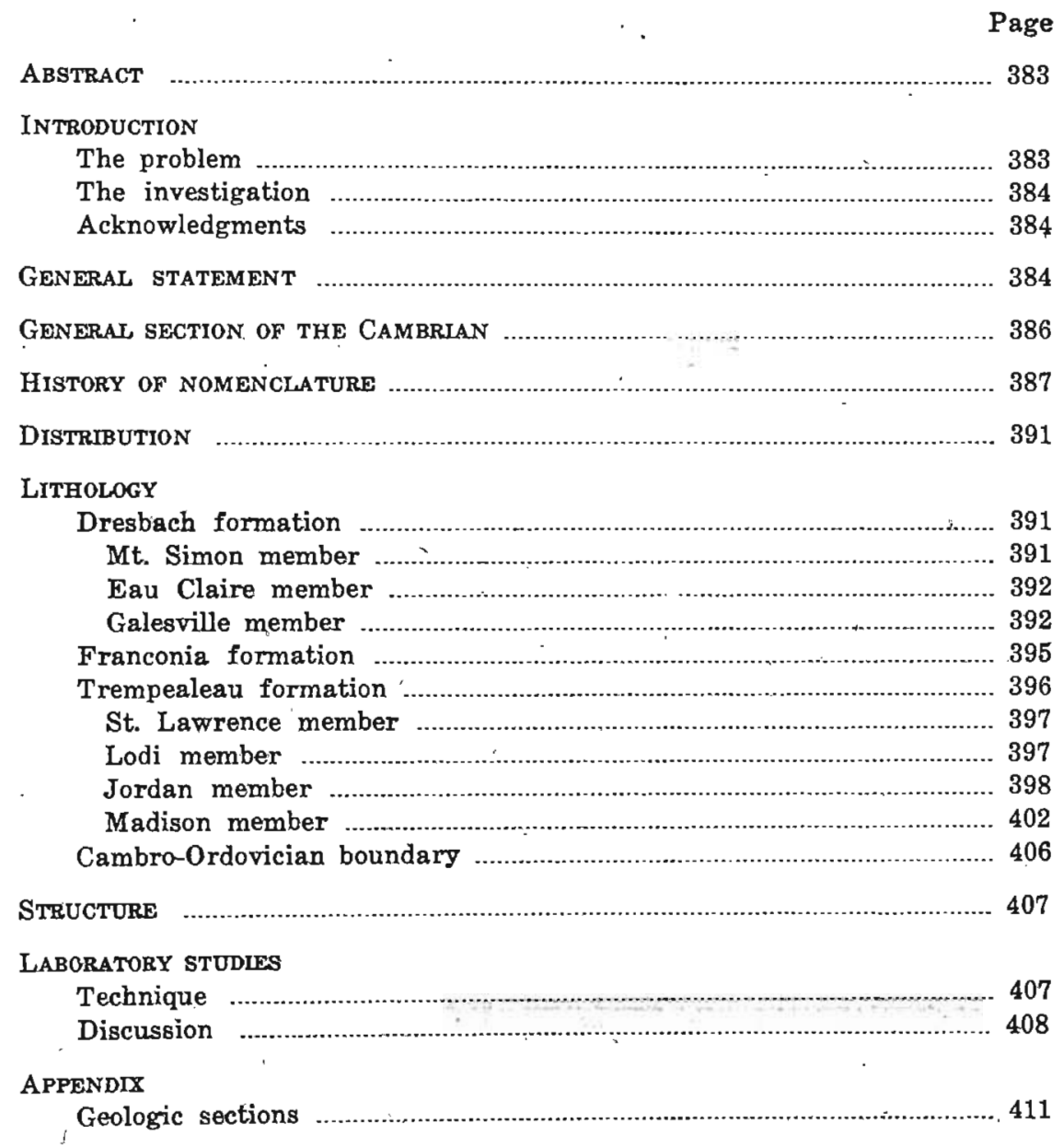




\section{ILLUSTRATIONS}

Plate

Facing

Page

1. Outcrop and subsurface contour map on the Cambrian of Iowa 384

2. A. Ironton-Galesville contact, exposure 103 392

B. Lodi siltstone, exposure 106, Fire Bell Hill, Lansing, Iowa 392

C. Massive upper portion of the Jordan sandstone, exposure 38 392

D. Ledgy character of the upper part of the Jordan sandstone, exposure 92

3. A. Sand-calcite nodules in the upper part of the Jordan, exposure 9.... 393

B. Madison sandstone, exposure 90 393

C. Flattened cylindrical structures in the upper part of the Jordan sandstone in a bluff exposure in $\mathrm{NE}_{1 / 4} \mathrm{NW} / 4 \mathrm{SW}_{1 / 4} \mathrm{sec}$. 22, T. 100 N., R. $5 \mathrm{~W}$.

D. Flattened cylindrical structures in upper part of Jordan sandstone, exposure 8

4. Cross section showing insoluble residues and mechanical analysesNew Albin to McGregor 406

5. Cross section showing insoluble residues and mechanical anlysesNew Albin west to Winneshiek County line 


\title{
CAMBRIAN STRATA OF NORTHEASTERN IOWA
}

\author{
BY WALTER C. SCHULDT
}

\begin{abstract}
The area of Cambrian sediments of northeastern Iowa has been studied with the dual aim of interpreting these rocks in the light of present knowledge of the stratigraphy of the Cambrian and of determining the nature and extent of lithologic variation over a small area.

Two cross sections are presented to show lateral and vertical variation of grain size and percentage of carbonate throughout the area. A structure-contour map, drawn on the Cambro-Ordovician boundary, shows several welldefined northwest-southeast trending structural highs within the area.

The Cambrian strata in northeastern Iowa are found to conform to the classification adopted by the ninth annual field conference of the Kansas Geological Society in 1935, and are subdivided into the Dresbach, Franconia, and Trempealeau formations in ascending order.

Detailed studies of the Madison member of the Trempealeau formation show that general characteristics such as fineness of grain, thin bedding, flat-pebble conglomerates, and green shale partings occur over the entire eastern half of the area, but that individual beds vary gretaly in lithology over a very short distance, and that it is nearly impossible to identify an individual bed from exposure to exposure. In the western half of the area, the member undergoes a complete change in character, becoming coarser grained and more massively bedded, so that differentiation from the remainder of the Jordan member is very difficult.
\end{abstract}

No evidence is found to indicate the presence of any pronounced breaks in the Cambrian sequence.

\section{INTRODUCTION}

\section{The Problem}

Since the work of Calvin, ${ }^{1}$ there has been no systematic investigation of the Cambrian strata exposed in Iowa, and the only published work of any nature regarding the exposed Cambrian in the state has been that in connection with the production of a new geologic map for Iowa by Tester ${ }^{2}$ in 1937. In the adjacent states of Wisconsin and Minnesota, considerable recent work has done much to advance ideas regarding Cambrian stratigraphy, and correlation has undergone considerable evolution. It seems advisable; therefore, that these sediments in Iowa be studied in the light of present correlations and knowledge, in particular since the out-

${ }^{1}$ Calvin, Samuel, Geology of Allamakee County:-Yowa Geok Survey; vol. 4, pp. 54-61, 1895.

Trester, A. C., Geologic map of Iowa, Iowa Geol. Survey, .1937. 
crop area in Iowa lies adjacent to a large area of Cambrian sediments covered by younger rocks and inaccessible to study except through the medium of subsurface data.

Because of the abundance and excellence of exposures and the limited area of outcrop, a detailed study has been made of Oneota-Madison-Jordan relationships with the aim of determining the degree of lithologic variation over a small area, and the discovery of any "marker" beds which might be of value in subsurface correlation.

\section{The Investigation}

Fourteen weeks, during the field seasons of 1938 and 1939, were spent in an intensive study of the outcrop area represented in plate 1. One hundred forty-seven sections were described in detail and an altimeter elevation was obtained for each.

During the fall and winter of 1939 , mechanical analyses and insoluble residue determinations were made on 500 channel samples collected during the previous summers.

Many of the described sections are included in the accompanying appendix, and results from the laboratory work have been plotted on two large cross sections to show lateral changes in grain size and sorting.

\section{Acknowledgements}

The writer wishes to express his gratitude to Dr. A. C. Trowbridge, who directed field and laboratory work and under whose general supervision this report was written, and to acknowledge the aid extended by Mr. Gilbert $\mathrm{O}$. Raasch, who very kindly examined and identified all the fossils collected. Gratitude is also extended to Professor Shorey of the mining department of the University of Wisconsin; who kindly permitted the writer to use the equipment and laboratories of the mining school to crush the samples. Mr. Herbert Yoho, graduate student, was employed during preparation of insoluble residues.

\section{GENERAL STATEMENT}

The Cambrian strata of the Upper Mississippi Valley, and of Iowa in particular, consist almost entirely of sandstones and siltstones with one thin band of dolomite and considerable dolomite 


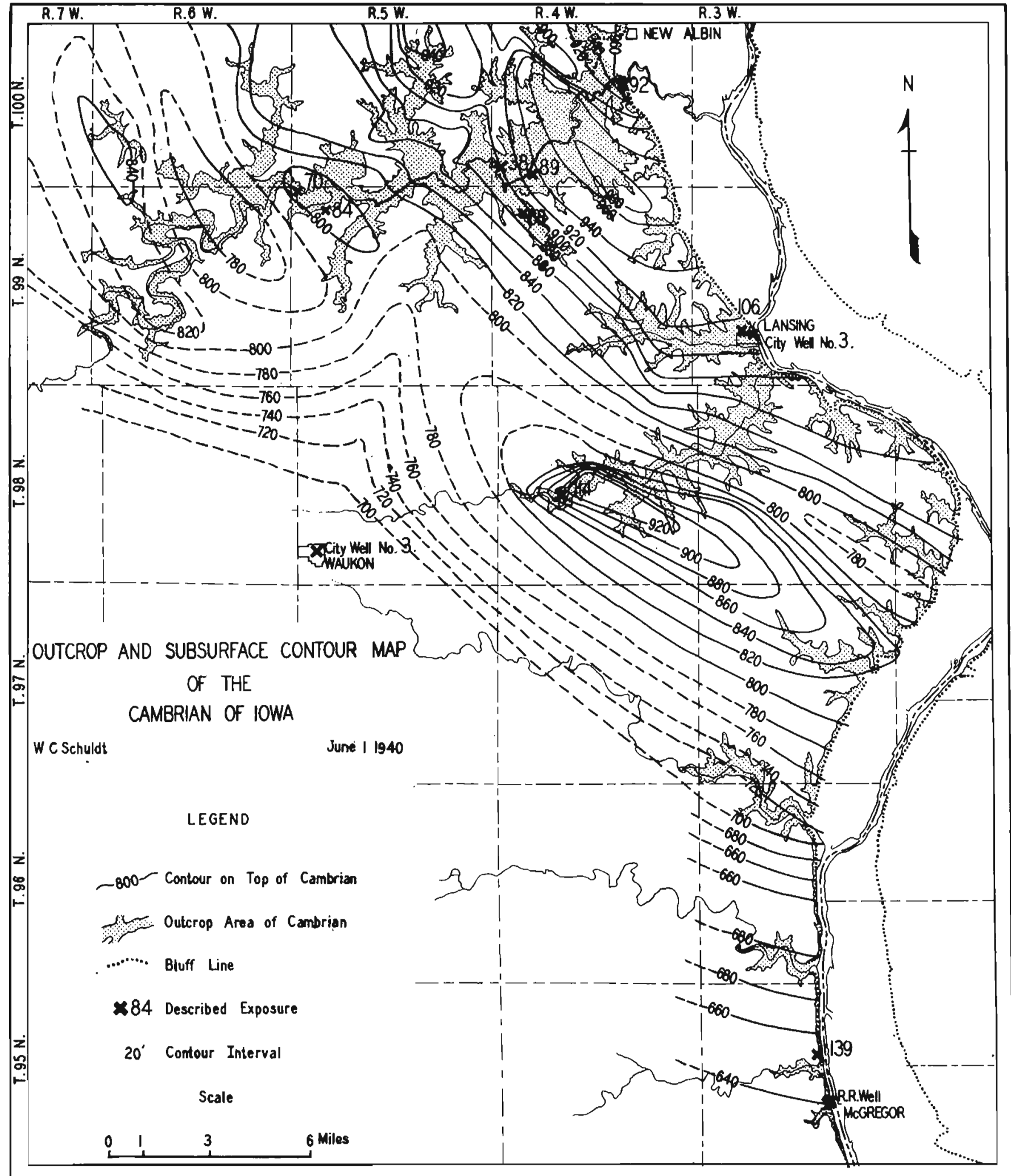


cementation near the top. The sandstones belong wholly to the Upper Cambrian or St. Croixan series, and are divided into the Dresbach, Franconia, and Trempealeau formations in ascending order. Table 1, a generalized section for the Cambrian of northeastern Iowa, shows the present classification, including members, with a general description of the lithology and approximate thicknesses.

Fossils are rare and fragmentary throughout most of the section, and correlations have been made primarily 'on the basis of lithologic evidence: Almost all contacts are transitional and no evidence was found for any major break. Despite this fact, however, in the majority of cases, contacts can be placed with considerable assurance on the basis of lithology.

Because the Dresbach formation is questionably represented by one small exposure showing only the topmost beds, lithologic descriptions for the members of the Dresbach formation have of necessity been taken from a study of the subsurface geology as interpreted from well cuttings.

The Franconia in this area is poorly exposed and very difficult to correlate owing to the sparsity of fossils and small exposures. For this reason, thicknesses and descriptions for members of the Franconia have been taken from published descriptions of Wisconsin sections. 
TABLE 1

General Section of the Cambrian of Northeastern Iowa

St. Croixan series

Trempealeau formation

Madison member

Fieet

Fine-grained, thin-bedded, cross-laminated, dolomitic sandstone, conglomeratic and green shaly in parts.

Jordan member

Van Oser facies

Brown, cparse-grained, well-sorted, unconsolidated, massive sandstone with numerous sand-calcite nodules and dolomitic ledges in upper part, grading, down into:

Norwalk facies

Fine-grained, well-sorted, massive sandstone, unconsolidated in upper part, becoming strongly cemented and blocky at base

- Lodi member

Buff, thin-bedded, siltstones to fine-grained sandstones, fossiliferous in some beds.

St. Lawrence member

Pink, sandy, glauconitic dolomite in upper part and thinbedded, glauconitic siltstones below.

Franconia formation

Bad Axe member Friable, green-gray, fine-grained sandstone to siltstone, sparsely fossilifeous.

Hudson member

Buff to green, laterally variable, thick-bedded, fine-grained, flour-like sandstone beds differentiated principally on basis of faunal criteria.

Goodenough member

Cross-laminated greensands with irregular, buff mottled appearance at top, underlain by thin-bedded, fine-grained, micaceous sandstone, in turn underlain by fine-grained, calcareous, glauconitic sandstone at base

Ironton member

Buff to brown, massive, coarse-grained, well to poorly sorted, fossiliferous sandstone.

Dresbach formation

Galesville member

White, clean, fine- to medium-grained, well-sorted, unconsolidated, nonfossiliferous sandstone.

Eau Claire-member

Buff, fine-grained, slightly glauconitic, fossiliferous sandstones to siltstones.

Mt. Simon member White to buff, medium- to coarse-grained, unconsolidated, nonfossiliferous sandstones 


\section{HISTORY OF NOMENCLATURE}

Several recent summaries of the development of stratigraphic knowledge and correlation of the Cambrian strata in the Upper Mississippi Valley make a detailed review of the history of Cambrian nomenclature unnecessary. It is therefore intended to present only an outline of this phase of the subject, drawing freely upon the historical portions of other papers published recently and extending beyond them to include more recent work.

The Cambrian sediments of the Upper Mississippi Valley were studied by Owen as early as 1848 in a geological survey of Wisconsin, Iowa and Minnesota. In Owen's final report ${ }^{3}$ of 1852 , the Cambrian strata were designated as Formation 1 and were correlated with the Potsdam of New York State. No names were proposed, but six divisions or units were recognized and designated alphabetically. Winchell ${ }^{4}$ in 1874 , working on the Minnesota section, proposed the name St. Lawrence for limestone beds being quarried for building stone near that village (now non-existent). He also used the term Jordan, but both Jordan and St. Lawrence as of Ordovician age, confusing them with the New RichmondOneota sequence and placing the top of his St. Croixan series at the base of the St. Lawrence.

Irving ${ }^{5}$ in 1875 , working in the Cambrian of Wisconsin, applied the names Madison, Mendota, and Potsdam to the strata included in Owen's Formation 1. The Madison applied to what is now the Madison-Jordan sequence, the Mendota was equivalent to the Lodi and St. Lawrence of today, and the Potsdam included all of the Cambrian below the base of the St. Lawrence. In 1882, Wooster ${ }^{6}$ applied the term Eau Claire Trilobite Bed to the middle shaly portion of the sandstone now comprising the Dresbach formation, and. used the term Eau Claire Grits for the clean coarse rounded and frosted sandstone underlying the Eau Claire beds. He likewise proposed the term Hudson Trilobite Bed for the beds now known as the Hudson member of the Franconia. In 1886, Winchell ${ }^{7}$ correlated the St. Lawrence of Minnesota with Irving's Madison of Wis-

\footnotetext{
3Owen, D. D. Report of a geological survey of Wisconsia, Iowa and Minnesota and incidentally a portion of Nebraska Territory, Lippincott, Grambo and Co., Philadelphia, pp. 52-58, 1852.

"WInchell, N. H., The geology of the Minnesota Valley: Minnesota Geol. and Nat. History

Survey 2d Ann. Rept., pp. 147-156, 1874 .
SIrve. R. D.. Note on gome new points in the elementary stratification of the primordial and Canadian rocks of south central Wisconsin: Am. Jour. Sci., 3d ser., vol. 9, op. 441-442, 1875. "Wooster, L.. C., Geology of the lower Saint Croix district: 'Geology of Wisconsin, vol, 4, pp. 112-116, 1882.

TWinchell, N. H., Revision of the stratigraphy of the Cambrian in Minnesota: Minnesota Geol. and Nat. History Survey 14th Ann. Rept:, pp. 325-337, 1886.
} 
consin, placing both formations within the St. Croixan. He repeated this correlation in 1888 using the term Dresbach for the beds now comprising the Galesville and Eau Claire members and designating the underlying sandstone as Hinckley.

Hall $^{8}$ in 1911 and Norton ${ }^{9}$ in 1912, working under the auspices of the U. S. Geological Survey, expanded the St. Lawrence downward to include most of the beds now known as Franconia.

In 1897, C. P. Berkey ${ }^{10}$ named the Franconia -sandstone from exposures in the vicinity of Franconia, Minnesota. Until 1911, the Madison-Mendota sequence of Irving had been in common use in Wisconsin, where it was considered by Winchell ${ }^{11}$ as equivalent to the Jordan-St. Lawrence sequence of Minnesota. In 1911, Ulrich $^{12}$ questioned the position of the Mendota and in $1914 \mathrm{he}^{\mathrm{s}}$ placed both Madison and Mendota above the Jordan, introducing the terms Jordan and St. Lawrence into Wisconsin. For the next 20 years there was much controversy concerning the position and existence of the Mendota. It has finally been generally accepted by Trowbridge, Atwater, ${ }^{14}$ and others ${ }^{16}$ and by Twenhofel, Raasch and Thwaites ${ }^{16}$ that the Mendota of Ulrich is non-existent and that the beds ealled Mendota by him are actually the equivalent of the St. Lawrence of Minnesota. The controversy, however; has caused the redefinition and decline in importance of the term Madison, which originally including all Cambrian beds above the St. Lawrence, was first restricted to the fine-grained, thin-bedded, dolomitic transition beds at the top of the Jordan, and finally in later publications was relegated to member status. In Walcott's publication of 1914, Ulrich ${ }^{17}$ applied the term Franconia to the Wisconsin section, restricting the St. Lawrence to its original limits. He also restricted the Dresbach to the beds below the Franconia and above the Eau Claire beds of Wooster, ${ }^{18}$ and applied the

\footnotetext{
${ }^{8}$ Ha 1, C. W., Meinzer, O. E., and Fuller, M. L.. Geology and undergrownd waters of southern Minneeota : U.'. S. Geol. Survey Water-Supply Paper 256, p. 86, 1911.

Narton, W. H. and others, Underground water resources of Iowa: U. S. Geol. Survey Water-Supply Paper 298, p. 60, 1912.

10 Pnrkev, C. P., Geology of the Saint Croix Dalles: Am. Geologist, vol. 20, pp. 878, 377, 1897. wWinchell. N. H., Revision of the stratigraphy of the Cambrian in Mipnesota: Minnesota Geol. and Nat History Survey 14th Ann. Rept, pp. 825-387, 1886.

"Ulrich, E. O., Revision of the Paleozoic systeras: Geol. Soc. America Bull., vol. 22, pl. 27, 1911.

${ }^{23}$ Ürich, 'E. O., in Wajcott, C. D., Cambrian geology and paleonthology: Smithsonian Misc.

Coll., vol. 57, p. 854, 1914.

A C Atwater, G. I. Stratigraphic problems in the upper Mississippi Valley: Geol. Soc. America Bull., vol. 45, p. 79, 1984.

15Trowbridge, A. C., and others, Kansas Geol. Soc. Guidebogk, 9th Ann. Field Conf., p. 18, 1986 .

10Twenhotel, W. H., Raasch, G. O., and Thwaites, F. T., Cambrian strata of Wisconsix: Geol. Soc. America Bull, vol. 46, p. 1690, 1935.

17Ulrich, E. O., in Walcott, C. D., op. cit.

19Wooster, L. C., Geology of the lower Saint Croix district: Geology of Wiseousiri- vol: pp. 112-116, 1882 .
} 
term Mt. Simon to the clean, coarse, unfossiliferous sandstones underlying the Eau Claire beds.

Ulrich $^{10}$ in 1920; used the term Mazomanie formation for glauconitic beds which, he asserted, overlapped the Franconia in northeastern Wisconsin, and were therefore younger in their entirety than the glauconitic beds of western Wisconsin. The term was used by Thwaites ${ }^{20}$ but the latter disclaimed responsibility for the belief that the Mazomanie is younger than the Franconia, and in 1931 Pentland $^{21}$ showed by heary mineral studies that the Mazomanie of eastern Wisconsin is a close equivalent to the Franconia of western Wisconsin.

In 1924, Ulrich ${ }^{22}$ proposed the term Trempealeau to replace the variously interpreted St. Lawrence and extended it upward to include the lower fine-grained Norwalk phase of the Jordan. Stauffer ${ }^{28}$ objected to the inclusion of the Norwalk in the newly proposed Trempealeau, since at Jordan, the type section for the Jordan formation, only the finer grained Norwalk phase is present. He therefore continued to use the Minnesota term St. Lawrence, excluding from it a part of the Franconia. He included the remainder of the Franconia and part of the present Galesville in his Franconia, and included the remainder of the Galesville and the Eau Claire in his Dresbach formation. He also included the Hinckley sandstone as equivalent to the Mt. Simon of the Wisconsin section. Ulrich and Resser, 24 in 1930 followed Uirich's classification of 1924 with the exception that the Eau Claire is expanded to include the present Mt. Simon. In publishing a geological map of Minnesota by Grout and others, ${ }^{25}$ the Minnesota Geological Survey in 1932 followed Stauffer's classification of 1927. 1111 解

In 1934, Trowbridge and Atwater, ${ }^{26}$ reviewing the stratigraphic problems of the Upper Mississippi Valley, suggested that the three divisions of the strata underlying the Franconia, while

\footnotetext{
${ }^{10}$ Ulrich, E. O., Major causes of land and sen oscillations: Washington Acad. Sci. Jour., vol. 10 , p. 74-76, 1920 .

20.Thwaites, F. T., Paleozoic rocks found in deep wolls in Wisconsin and northern Illinols:

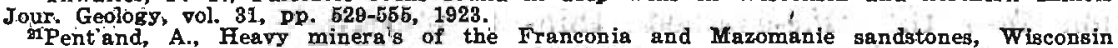
Jour. Sedimentary Petrology, vol. 1, pp. 23-3\%, 1931.

Jour. Sedich, E. O. Notes on new names. in the tahle of formations and on phrsical evidence of breaks between Paleozoic systems in Wisconsin: Wisconsin Acad. Sci. Arts and Letters Trans,y vol. 21, p. 83, 1924. ${ }^{29}$ Stauffer, C. R., Age of the Red Clastic series of Minnesota: Geol. Soc. America Bull.. vol. 88. $n n .472-474,1927$.

MUlich, E. O., and Resser, C. E., Cambrian of the upper Mississippi Valley: Milwaukee Public Mus. Bull., vol. 12, no. 1, p. 11 , 1930.

2. F. F.. and others, Geo ogie map of Minnesota, Minnesota Geal Survey, 1982

Mrowbridge, A. C.; and Atwater, G. I., Strationaphic problems in the upper Misgigaippl Valley : Geol. Soc. America Bull., rol. 46, D: 79, 1984.
} 
generally recognizable, were at the same time transitional from one to the other and were consequently more nearly of member than of formational rank. They therefore proposed to use the term Dresbach in a formational sense to include all three horizons, and suggested the new name Galesville for the sandstones underlying the Franconia and overlying the Eau Claire beds. They recognized the Franconia as a formation and restricted the St. Lawrence formation to include only the fossiliferous Lodi siltstone member and the Blàck Earth or St. Lawrence dolomite member. They suggested that the term Jordan be retained in a formational sense and discouraged the use of any further subdivisions on the basis that these subdivisions could be identified only in comparatively few sections.

During the preparation of the guidebook for the ninth annual Kansas Geological Society field conference in Iowa, Wisconsin and Minnesota ${ }^{27}$ in 1935 , several conferences occurred in an attempt to reach an agreement regarding the classification of the Cambrian. Complete agreement among all three states was not attained, but by conferences, correspondence and additional field work, a classification evolved which has proven to be the groundwork for a common classification of the Cambrian of the Upper Mississippi Valley. It differs from that of Trowbridge and Atwater in that it uses the term Trempealeau in a formational sense to include the St. Lawrence, Lodi, Jordan, and Madison sandstones as of equivalent member rank, but follows the Trowbridge and Atwater classification in the usage and subdivision of the terms Dresbach and Franconia. Twenhofel, Raasch and Thwaites ${ }^{29}$ follow the Conference classification without exception.

In the most recent publications on the Cambrian of the Upper Mississippi Valley, Stauffer, Schwartz and Thiel ${ }^{29}$ in 1939 and Stauffer and Thiel $^{30}$ in 1941 have revised the Minnesota classification in the light of more recent work. They follow Trowbridge and Atwater closely but substitute the Minnesota term Nicollet Creek for the term Black Earth, and subdivide the Jordan formation into the fine-grained, thin- to massive-bedded, dolomitecemented Norwalk member below, and the coarse-grained, un-

\footnotetext{
27Trowbridge, A. C., and others, Kansag Geol. Soc. Guidebook 9th Ann. Field Conf., p. 18, 1935.

25Twenhofel, W. H., Raasch, G. O., and Thwaites, F, T., Cambrian strata of Wisconsin:

Geol. Soc. America Bull., vol. 46, p. 1690,1935 .

Geol. Soc. America Bull, vol. 46, p. 1690, 1935., G. A., St. Croixan classification of Minnesota: ${ }^{20}$ Stauffer, C. R., Sehwartz. G. M., and Thie,
Geol. Soc. America Bull., vol. 50, p. 1228, 1989.

Geol. Soc. America Bull., vol. 50, p. 1228, 1989.
arstanffer, C. R., and Thie,. G. A., The Pa'eozoic and related rocks of southeastern Minnecota : Minnesota Geol. Survey Bull. 29, pp. 9, $80,1941$.
} 
consolidated, massive Van Oser member above. For the area south of Redwing, Minnesota, the Minnesota equivalent of the Madison member of Wisconsin and Towa is probably included in the Jordan and in other parts of Minnesota the Madison appears to be missing. ${ }^{31}$

\section{DISTRIBUTION}

Exposures of Cambrian strata in Iowa are limited almost entirely to Allamakee County in the northeast corner of the state. Oneota dolomite and younger rocks cap all of the upland, restricting the outcrop area of the Cambrian to the valley slopes and bottomlands. The boundary of the outcrop area shown on plate 1 is actually the line of intersection of the structure-contour map with the topographic map of the area. In cases where the point at which Cambrian beds disappeared below river level had been determined by traverses, this point has been used to determine the distance to which the outcrop area extends up the valley.

\section{LITHOLOGY \\ Dresbach Formation}

With one possible exception, members of the Dresbach formation do not outcrop in Iowa; the topmost beds normally occur below river level. In the vicinity of exposure 103, approximately midway' between Lansing and New Albin, the Mississippi River valley cuts diagonally across a small anticline, and in the core of - this structure approximately 2 feet of what is believed to be Galesville is exposed. At New Albin the top of the Galesville belongs somewhere within the 165 feet of valley fill penetrated by the city well, (described by Norton ${ }^{32}$ ), before the first rock stratum was entered. At Marquette, at the extreme south end of the area of outcrop, the top of the Dresbach occurs 330 feet below the river level. The discussion of members of the Dresbach formation must, therefore, be taken wholly from subsurface studies and must necessarily be less accurate and detailed than discussion relating to the upper formations.

\section{Mt. Simon Member}

The only information available on the Mt. Simon member is

axTrowbridge; A. C., Personal communication.

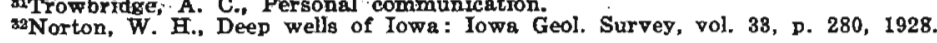


found in the rather generalized record of the first deep well at Lansing, reported to have passed completely through the Cambrian to enter the underlying crystalline rock. No properly preserved samples from this well are available but a tube made up from cuttings saved during drilling is in the hands of a resident of Lansing. Norton ${ }^{33}$ examined this tube and prepared a generalized section, and during the course of work in the vicinity of Lansing, the writer examined the tube and prepared a section which agrees in its essential parts with that of Norton (see p. 418). The driller reports this well stopped upon entering "hard crystalline rock" which in this case must be taken to mean an igneous or metamorphic rock of pre-Cambrian age. If this is true, the Mt. Simon is 323 feet thick in this vicinity. The writer, however, could find no evidence to support the statement that crystalline rock was entered for the tube showed no igneous material at all. It is, therefore, believed that a thickness somewhat greater than 323 feet may be assigned to the Mt, Simon in this locality.

The Mit. Simon in this section is uniformaly coarse-grained, fairto well-sorted sandstone, clean except for four 7- to 10-foot bands of clay-coated sandstone distributed throughout. The sandstone varies from white to yellow to brown in color, and ranges from curvilinear to sub-round in shape. The 'grains are well-frosted and the unit bears no evidence of calcareous cementation or glauconite.

\section{Eau Claire Member}

The Eau Claire beds in the Lansing deep well are demarked above and below by sharp breaks in lithology. Though not exposed in the area studied, it is found at a depth of 291 feet below the curb of the Lansing well and is shown by the tube to be approximately 134 feet thick. Examination of the tube shows this member to consist of very fine-grained sandstone to siltstone, white to orange in color, and slightly micaceous and glauconitic. There was no evidence of fossils.

\section{Galesville Member}

The Galesville member is characteristically composed of medium-grained, clean, white sandstones and is defined as clean, unfossiliferous, unconsolidated sandstones, bounded above by the coarse- to very coarse-grained and sometimes fossiliferous sand-

\footnotetext{
Norton, W. H., and others, Underground waters of the northeast district: Iowa Geol. Survey, vol. 21 , p. $295,1912$.
} 


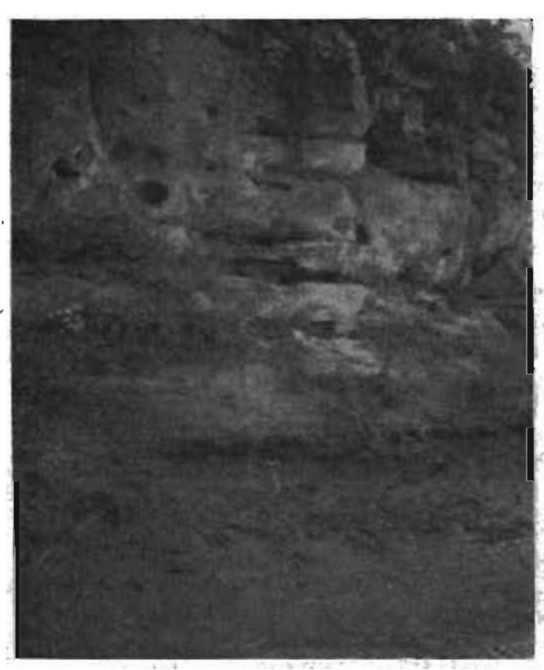

A

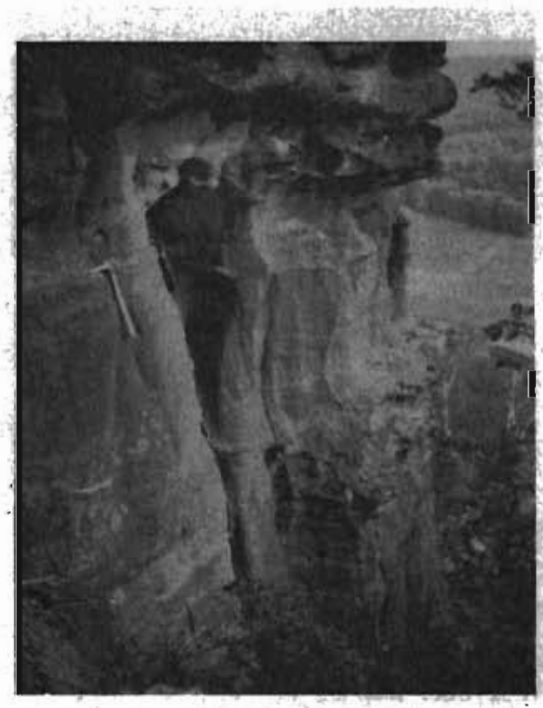

$\mathrm{C}$

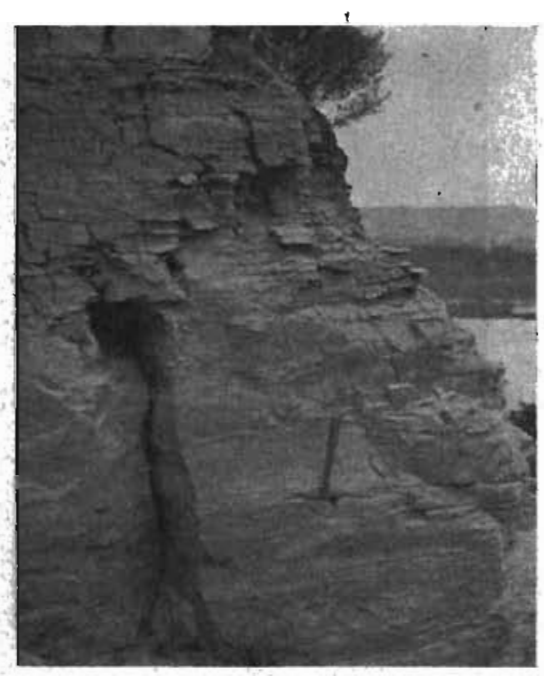

B

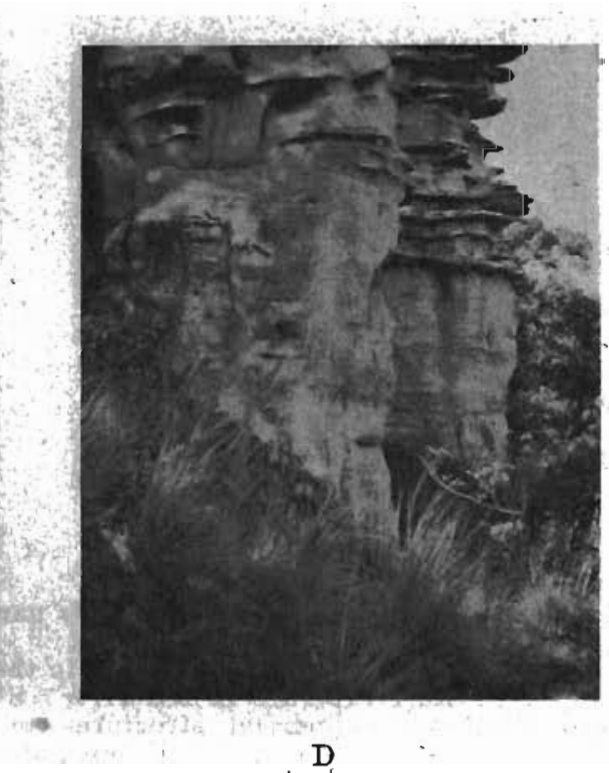

A. Ironton-Galesville contact, exposure 103.

B. Lodi siltstone, exposure 106, Fire Bell Hill, Lansing, Iowa.

C. Massive upper portion of the Jordan sandstone, exposure 38 .

D. Ledgy character of the upper part of the Jordan sandstone, exposure 92. 


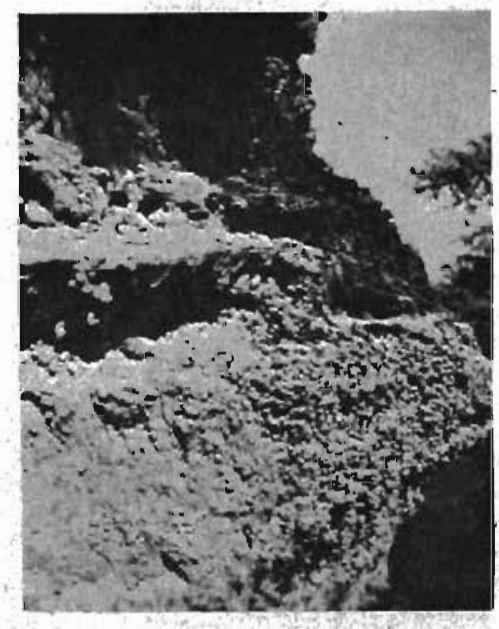

A

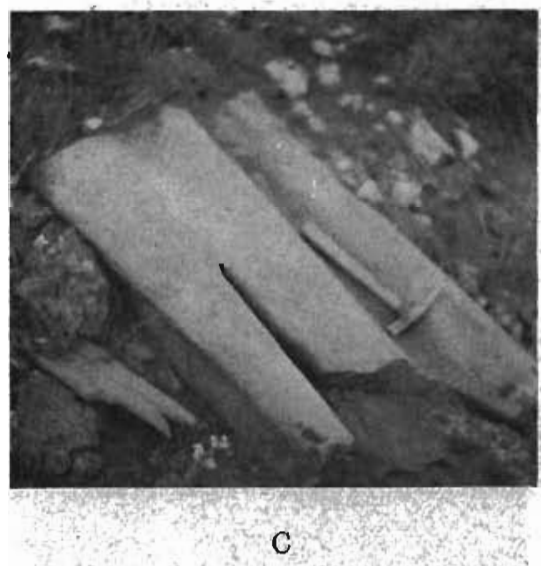

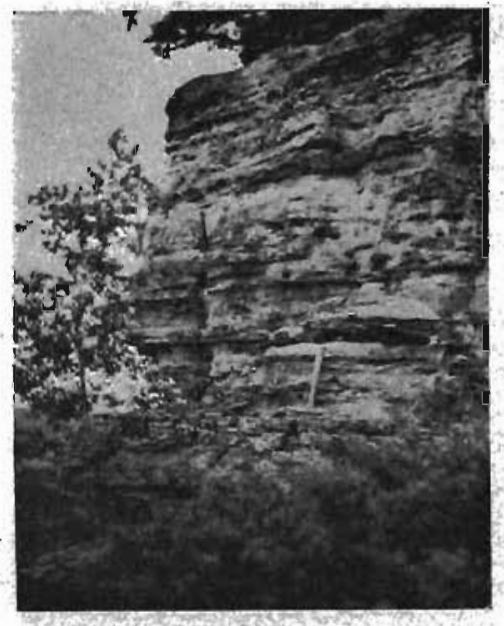

B

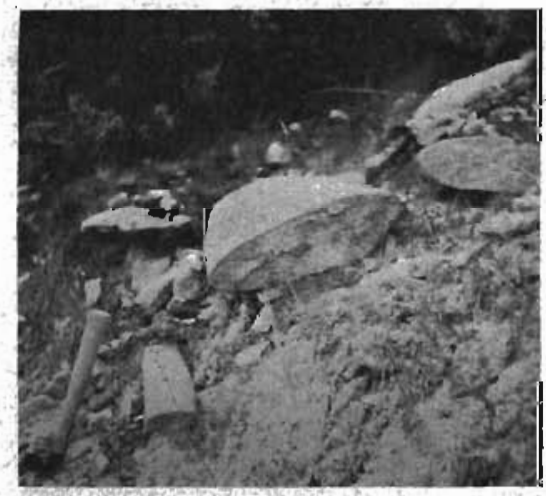

D

A. Sand-calcite nodules in the upper part of the Jordan, exposure 9.

B. Madison sandstone, exposure 90 .

C. Flattened cylindrical structures in the upper part of the Jordan sandstone in a bluff exposure in $\mathrm{NE}_{1 / 4} \mathrm{NW}^{1 / 4} / \mathrm{SW}_{1 / 4} \mathrm{sec} .22, \mathrm{~T}, 100 \mathrm{~N}$., $\mathrm{R} 5 \mathrm{~W}$.

D. Flattened cylindrical strugtures in upper part of Jordan sandstone, exposure 8. 
stones of the Ironton member of the Franconia, and below by the fine-grained to silty, slightly glauconitic and fossiliferous sandstone of the Eau Claire member of the Dresbach. Both contacts may be gradational, making exact delimitation of the member difficult. The lower and middle portions of the Galesville are nowhere exposed in Iowa, but exposure 103, located near the axis of a structural high, shows $2 \frac{1}{2}$ feet of fine-grained, well-sorted, unconsolidated, massive sandstone, believed to be the upper $2 \frac{1}{2}$ feet of the Galesville, (see pl. 2, A) underlying 19 feet of coarsegrained, fossiliferous Ironton sandstone.

At Lansing, in the city well, the Galesville consists of 77 feet of clean, white, coarse-grained, well-sorted, unconsolidated sandstone, underlain by 17 feet of coarse- to very coarse-grained, unconsolidated sandstone: Of the upper 77 feet, a portion of approximately 20 feet must be allotted to the Ironton member of the Franconia since the overlying pale-green, micaceous siltstone or shale obviously belongs to the Goodenough member of the Franconia. The section thus interpreted comprises 74 feet of Galesville sandstone beginning at 217 feet below the curb of the city well.

At Marquette, in Clayton County, the Chicago, Milwaukee, St. Paul and Pacific Railroad well shows 90 feet of buff, medium- to coarse-grained, well-sorted, unconsolidated sandstone beginning 330 feet below the curb. Though thicker than the Galesville in the Lansing well, there is some doubt as to whether the complete thickness is shown here, since the drawing in of the Eau Claire contact is based solely upon the beginning of slight tendencies toward dolomitization.

At Waukon, a city well drilled in 1914 shows the Ironton and Galesville sandstones to fall between 780 and 870 feet below the well curb, but the exact range and lithology are unknown, since there are no samples for this interval.

\section{Franconia Formation}

The Franconia formation' includes all beds from the base of the unnamed conglomerate member, underlying the- St. Lawrence member of the Trempealeau formation, to the top of the clean, white, medium- to coarse-grained, unfossiliferous Galesville sandstone member below.

Though several exposures of the Franconia were found and described in the area studied, little could be done with regard to sub- 
division, since the entire sequence is a greensand succession containing virtually no fossils. In. general, the Franconia in this area consists of fine-grained, well-sorted, angular sandstone, moderately glauconitic throughout and with occasional bands high in glauconite. Most exposures are fragmentary and so widely separated as to prevent any attempt to make a composite section on the basis of elevations. At Lansing, approximately 46 feet of section is exposed with 15 feet concealed between the lowermost St. Lawrence beds and the uppermost Franconia. The beds exposed undoubtedly belong in part to the Bad Axe member, and in part to the Hudson member, but the placing of the contact between these members without the aid of paleontological.evidence is extremely hazardous. In exposure 89 (see p. 414), one thin dolomitized bed was found containing representatives of the Prosaukia misa faunule and the Ptychaspis faunule no. 5, both of which occur slightly below the middle of the Hudson, as indicated by Raasch, ${ }^{34}$ who studied the specimens. On the basis of this evidence, the Bad Axe-Hudson contact has been tentatively placed between units 5 and 6 . The Ironton and base of the Goodenough occur in exposure 103. The basal bed of the Goodenough is a fine-grained, glauconitic sandstone, well-sorted and slightly cemented in parts. The Ironton, in the single exposure examined, consists of 19 feet of medium- to very coarse-grained, very poorly sorted, unconsolidated sandstone (see pl. 2, A) with fragments and shells identified" by Raasch as "Parobolus littoralis" from the Cameraspis convexus zone of the Ironton.

Underlying the Ironton in this exposure are 2 feet of white, fine-grained, nonfossiliferous sandstone believed to be Galesville. The contact between these two formations is sharp and distinct but there is no evidence of erosion.

A thickness of approximately 160 feet is obtained for the Franconia by interpolation between the Victory section described by Twenhofel, Raasch and Thwaites (in Wisconsin, directly across the Mississippi River from New Albin in the extreme northeast corner of Allamakee County, Iowa) and exposure 106 at-Lansing.

\section{Trempealeau Formation}

The Trempealeau formation, and in particular the topmost members, the Jordan and Madison sandstones, form by far the

\footnotetext{
sRarach, G. O., Personal communication.
} 
major part of the available Cambrian exposures, and nearly every spur and ravine bed in the northeastern corner of Allamakee County exposes at least a portion of one or the other. The reason for this is that the upland is capped with very resistant dolomite, a circumstance which readily permits the formation of bluff exposures in the well-dissected country of the Driftless Area. Although complete sections of the Trempealeau are comparatively rare, a sufficient number occur to obtain an average figure for the thickness of this formation. At the Victory section, the Trempealeau is 173 feet thick. In exposure 106 at Lansing, it is 184 feet thick. At exposure 114 in the western half of Center Township, it is approximately 160 feet thick, and at Waukon, it is 150 feet thick. In the Trempealeau formation there-is a pink dolomite at the base which grades upward through the Lodi siltstones to the fine-grained dolomitic siltstones and very fine-grained sandstones of the lower part of the Jordan, becoming progressively coarser until, at the top, the grain size is predominantly coarsemedium to coarse. In the overlying Madison, dolomitization increases upward and sand sizes again decrease and are predominantly fine-grained.

\section{St: Lawrence Member.}

In the area studied, the St. Lawrence member is a fine to medium crystalline, glauconitic, sandy dolomite, 2 inches to 2 feet thick. It is commonly pink to red in color but lacks the purple splotched appearance present in adjoining states. The dolomitic band is underlain by 5 to 20 feet of thinly bedded, slightly dolomitic, sparsely glauconitic siltstones to very fine-grained sandstones which, however, do not contain the greensand conglomerate often occurring in the lower portion of the St. Lawrence in Wisconsin.

The member is bounded above by the thinly bedded and partially reworked basal siltstones of the Lodi member and is underlain by the. Franconia greensands. The, St. Lawrence is only rarely exposed in the area studied, but from the evidence available, both upper and lower boundaries are gradational.

\section{Lodi Member}

The Lodi member of the Trempealeau is characteristically siltstone, though it normally contains up to 30 percent of very fine 
sand grains and may contain up to 30 percent of dolomite. The member commonly ranges from 20 to 30 feet in thickness and consists of buff, slabby, thin-bedded, dolomitic siltstone to very fine-grained sandstone (see pl. 2, B). From top to bottom there is strikingly little variation in lithology and the only outstanding characteristic is the tendency toward reworked zones and occasional conglomeratic bands near the base. The Lodi occurs commonly in the lower one third of the valley slopes, so that exposures are uncommon and often fragmentary with top or bottom or both concealed. From the-evidence available, however, it appears that both contacts are transitional for, at the top, the thin-bedded, slabby character of the Lodi gradually gives way to the more heavily bedded, blocky fractured, fine-grained, dolomitic sandstones of the base of the Jordan, and at the base, it grades within a very short distance through dolomitic siltstones to pink, glauconitic .St. Lawrence dolomite. Supposedly fossiliferous, the Lodi yielded fossils only in exposure 106 atop Fire Bell Hill in Lansing where one specimen of the Trilobite Diteelocephalus gracitis Ulrich and Resser, was collected from near the base of the Lodi. In all other localities search for fossils proved fruitless. Laterally the Lodi showš virtually no variation.

\section{Jordan Member}

The Jordan member, lying transitionally between the Madison member above and the Lodi siltstone below, comprises the bulk of the Trempealeau formation. The term Jordan is of long standing but has been variously applied and interpreted by different writters. In the past, it hās been considered as of formational rank, often rather indefinitely including the Madison beds and occasionly also the Lodi siltstones: In 1935; the classification prepared for the ninth annual field conference of the Kansas Geological Society $^{35}$ expanded the term Trempealeau to include Ulrich's Jordan (the present Van Oser facies) and Madison, reuniting the Norwalk and Van Oser facies and reducing the term Jordan to member rank. This has been generally accepted, except by Minnesota geologists, who prefer to retain the name Jordan in its formational sense beeause of its very widely established usage in that state.

Over the entire outcrop area of northeastern Iowa, the Jordan is remarkably uniform in thickness and lithology. It ranges from 100

\footnotetext{
Trowbridge. A. C., and others, Kansas Geol. Soc. Guidebook, 9th Ann. Field Conf., p. 18,
} 1935 
feet to 1.20 feet thick and consists of two easily recognizable lithologies. ' The lower of these two, considered here as the Norwalk facies, is a fine- to very fine-grained buff to white sandstone, 60 to 80 feet thick. Dolomitic to the point of having well developed blocky fracture at the base, it grades upward to unconsolidated sandstone which in some beds is entirely massive and in others weathers to thin beds a quarter of an inch thick. Though finegrained and very well'sorted, it occasionally incorporates thin beds or stringers of coarse sand. Occasional thinly bedded zones may contain innumerable worm borings, but no fossil fragments have been identified. Local dolomitization may occur well up from the base, or slight cementation may extend upwards for a considerable distance. Both large and small scale cross lamination is well developed in many places.

Overlying this fine-grained sandstone and separated from it by a variable thickness of transition beds, is the Van Oser facies, a coarse-grained, well to poorly sorted, buff to brown sandstone, entirely, unconsolidated except for secondary dolomitization in the form of ledges. This coarse facies ranges from 20 to 40 feet thick, is entirely barren of fossils, and is often completely massive except for large scale cross lamination which is common throughout (see pl. 2, C). Th upper 10 to 15 feet of the Jordan often has a very ledgy appearance occasioned by the selective deposition of secondary dolomite as cementing material along certain beds, while immediately adjacent beds above and below may be entirely unconsolidated. The mechanism of this deposition is not entirely clear, for while in many cases the cementation appears to have taken place along horizons of somewhat more perfectly sorted sandstone, permitting freer circulation of ground water, the reverse is also locally true, and dolomitization appears to have taken place within the more finely grained and occasionally slightly silty beds where circulation must certainly. have been slower. This ledge-forming tendency manifests itself both in bluff and ravine exposures, and in some cases ledges may become very numerous and closely spaced (see pl. 2, D). Still another feature to be found in the selective dolomitization mentioned previously is the occurrence in a few exposures within a limited area around exposure 8 in the northeastern corner of Allamakee County, of a single horizon of dolomite-cemented ledges weathering out of the less consolidated sandstone as flattened cylinders, often in parallel 
arrangement (see pl. 3, C and D). As a possible explanation for these structures, the writer is inclined to believe that comparatively well-sorted coarse sands were swept into the troughs of a somewhat lithified, strongly ripple marked portion of the sea bottom, and that subsequent flow of mineralized ground waters has been directed along the resulting channels of greater permeability, with the result that dolomite cementation has been more active and has strongly.cemented the more porous sand occupying the channel. Rarely, dolomitization may follow cross laminations, in which case a very odd reticulate structure is produced upon weathering. All of the dolomitization of the Van Oser facies is clearly of secondary nature and has very probably been derived by solution from the Oneota above. Where the Madison-Jordan contact is clearly distinguishable, ledges of silica-cemented sandstone occur rarely within the upper 1 to 2 feet of the Jordan. Since, as appears to be the case, such silica-cemented ledges occur only at the extreme top of the Jordan, they have, when present, been used to aid in placing the Madison-Jordan contact when other criteria are not so apparent.

Conglomerates are exceedingly rare, though one or two pebble stringers were found, and though uncommon, occasional green shale bands have been found to occur as much as 30 feet below the top of the Jordan. Where present, such green shale bands may range up to 3 inches in thickness but are invariably extremely local, pinching out in at least one direction within 15 to 20 feet. A further characteristic common to the coarse phase of the Jordan is the presence of numerous concretion-shaped spheres of calcitecemented sandstone. These nodules appear to have developed by growth of crystalline calcite around a nucleus, enclosing sand grains as the aggregate grew. These sand-calcite nodules range from the size of a pea to more than a foot in diameter and weather out intact to form a very nodular surface (see pl. 3, A) and may be found in abundance at the base of the exposure if the sandstone is unconsolidated.

The lithologies described above are general in their occurrence and have been noted in both Wisconsin and Minnesota. The lower fine-grained portion is equivalent to the beds at Jordan, Minnesota to which Winchell ${ }^{36}$ in 1874 originally applied that name.

\footnotetext{
*Winchell, N. H. The geology of the Minnesota Valley: Minnesota Geol. and Nat. Fistory Surves 2d Ann. Rept., pp. 147-156, 1874.
} 
The term. Norwalk was applied by Ulrich $^{37}$ in 1924 to the same beds in Wisconsin, and this name has come-into common usage. Foúr miles north of Jordan, Minnesóta, on Van Oser Creek, may be found the-coarse-grained sandstones overlying the Norwalk beds, The term Van Oser beds has come to be synonymous with the coarse-grained phase, and where the Jordan is considered as a formation, it is sometimes subdivided into the Norwalk and Van Oser members.

'Though a sharp plane of division does not always exist between the Norwalk and Van Oser lithologies, they are undeniably distinct and invariably present in the area studied, and are commonly no less 'sharp than are boundaries between other members of the Cambrian system. The writer, therefore, feels the 'use of the terms Norwalk and Van Oser as members is entirely valid where the Jordan is considered as a formation. Where the Jordan is considered as a member, it does not seem advisable to subdivide it further so that the terms are used primarily in a descriptive sense in the present discussion.

Within the area studied, the Jordan is characterized by its lack of lateral variation, the only changes being a slight increase in the abundance of dolomitic ledges and a decrease in the oceurrence of sand-calcite concretions southward along the Mississippi River. Westward along the Upper Iowa River there is little or no change.

The upper boundary of the Jordan is, for the most part the most clear-cut contact within the Trempealeau. Commonly it may be placed where the coarse-grained; massive, ledgy sands of the Jordan give way to the thin-bedded, conglomeratic, green shaly; basal beds of the Madison. Locally there may be a slightly undulatory surface with a relief of from 1 to 2 feet, but this is uncommon and, for the most part, the contact is horizontal and sharp. In Winneshiek County and the western part of Allamakee County this sharp line of demarcation fails and the Madison-Jordan contact is extremely difficult to establish.

The base is transitional, being placed as nearly as possible at the point where the rather masstve, blocky, sandy-silty beds of the base of the Jordan give way to the thin-bedded siltstones of the Lodi member. Mechanical analyses show no change in composition across the boundary.

MUrich, E. O. Notes on new names in the table of formations and on, physical evidence of breaks between Paleozoic systems, in Wisconsin: Wigcoingin Acad. Sci. Arts and Letters Trans., vol. 21, p. 88,1924 . 


\section{Madison Member}

The Madison member consists of a series of fine-grained, thinly bedded, dolomitic sandstones lithologically distinct, both from the underlying Jordan sandstones and the overlying Oneota dolomite. These beds are placed in the Cambrian by Twenhofel, Raasch, and Thwaites ${ }^{38}$ and in the Ordovician by Ulrich. ${ }^{99}$ Though differing considerably from the beds of the type section at Madison, Wisconsin, the Madison beds of Iowa have been found without reasonable doubt to be equivalent, at least in part, to the beds of the type section. Field studies, insoluble residues and mechanical analyses all indicate they are transitional in nature and that no prominent break is' present either above or below. Since this is the case, the Cambro-Ordovician boundary must be placed arbitrarily either at the top or at the base. Paleontologic evidence in adjacent areas indicates the Madison is of Cambrian age and the fact that the Madison sands are primarily sandstone, finer in grain and more perfectly sorted than the basal sands of the Oneota, incline the writer to the opinion that they should be placed with the Cambrian rather than the Ordovician.

Because of the abundance of exposures and variable lithology, a close study was made of this horizon in an attempt to determine the degree of variability and persistence of individual beds, and if possible to establish certain "marker" beds of value in subsurface studies.

In general, the lithology of the Madison is highly variable but certain features stand out as characteristic over considerable areas. Of these, one of the foremost is the thin-bedded character. In nearly all exposures in the eastern half of Allamakee County, beds range in thickness from a fraction of an inch to approximately 2 feet, commonly with all thicknesses represented in each exposure. Dolomite cementation along these bedding planes causes the rock to weather into a very characteristic ridge and valley type of surface (see pl. 3, B), often of considerable value in delimiting the member. Grain size, likewise, plays an important part in distinguishing the Madison from overlying and underlying beds. In general, the sand is fine-grained, grading to mediumgrained in occasional individual beds and, in some exposures,

\footnotetext{
Twenhofel, W. H., Rasch, G. O., and Thwaites, F. T., Cambrian strata of Wisconsin: Geol. Soc. America Bull., vol. 46, p. 1690, 1935.

OUlrich, E. O. Notes on new names in the table of formations and on physical evidence of breaks between Paleozoic systems in Wisconsin: Wisconsin Acad. Sci. Arts and Letters Trans., vol. 21, p. 88,1924 .
} 
grading to medium-grained toward the base. Alternations of grain size tend to distinguish beds and, within a single bed, to produce and emphasize cross lamination and to localize secondary calcite and dolomite cementation. The central portion of the Madison is characterized by an alternation of beds of buff, fine-grained, dolomite-cemented sandstone which weather to prominence and dark-gray, coarse-grained,' well-sorted, unconsolidated beds which weather recessively, both 6 to 10 inches thick. Grain size was also found to vary laterally from fine to medium or from medium to coarse, in places occasioning an entire change of appearance within 10 to 15 feet.

A third important characteristic is the kind and amount of dolomite cementation. Both primary and secondary dolomite and secondary calcite are present. As the Madison-Oneota boundary is approached, dolomitization becomes more and more prominent, resulting in a distinctly blocky dolomitic fracture for the upper part of the member. After passing upward across the boundary, dolomite becomes predominant with sand grains subordinate and often "floating" in the dolomite. This dolomite is considered as primary and indicative of an increasing percentage of $\mathrm{CaMg}$ $\left(\mathrm{CO}_{3}\right)_{2}$ deposition as Ordovician time began. In the central and lower portion of the Madison, dolomitization is selective, being concentrated along certain beds to the exelusion of others immediately adjacent, and often occurring as seams and partings following bedding planes and horizontal and cross lamination planes. Dolomitization of this sort is clearly a function of relative permeability of beds and horizons within beds and is of secondary origin. Calcite cementation is quite as common as dolomitization in some exposures, and appears to be entirely secondary.

Cross and horizontal lamination are common in all parts and exposures of the Madison. Where dolomitization is absent, truncation of cross-laminated and foreset beds are important in demarking bedding planes. Cross lamination may even appear occasionally in the strongly cemented upper portion of the member, indicating that perhaps at least a portion of this upper dolomite is secondary.

Characteristic of the Madison in the northeastern corner of Allamakee County and along the Mississippi River Valley southward to McGregor is the presence of numerous conglomerate zones. These conglomerates are predominantly of the thin flat- 
flake variety, though, occasional rounded or spheroidal pebbles occur. Few of the pebbles exceed half an inch in length and most of them are composed of pale-buff, fine-grained sandstone or siltstone, moderately cemented and firm. Most of the thin, flat flakes are oriented parallel to horizontal and cross lamination planes and bedding planes. They appear to be the result of the breaking up by occasional wave action of a thin, partly lithified layer of silty mud. Conglomerates of this nature may be limited to one or two beds, 8 to 10 inches thick, in which case they are apt to occur near the base, or they may be general throughout the entire lower portion of the member. In the upper portion, they are rare. In the opinion of the writer, there is nothing significant in these conglomerate zones as indicative of a time break, but rather that they perhaps indicate a restriction of the sea or at least a shallowing of the water with consequent increased effect by wave action.

Also characteristic of the Madison is the presence of occasional horizons carrying abundant green shale partings. The shale is leek green, dense and structureless with an irregular fracture, and these partings and seams of green shale, like the conglomerates, may be concentrated into a band 1 to 2 feet above the base, or may occur indiscriminately throughout the entire lower half of the Madison. They have not been observed in the upper portion of the unit, but occur rarely in the lower part of the overlying Oneota. Occasionally green shale pebbles may be found in the conglomerates, and often the flakes, oriented parallel to cross and horizontal laminations, are of green shale or the buff, weathered equivalent.

Locally, in one or two somewhat questionable instances, sandcalcite nodules and aggregates have been found in the lower portion of the Madison, but this is unusual and sand-calcite concretions may definitely be considered as a characteristic of the Jordan.

In the northeastern corner of Allamakee County, the Madison ranges from 18 to 22 feet in thickness, and maintains this thickness as far south as McGregor in northeastern Clayton County where the Cambrian sediments dip below river level. Westward, however, the aggregate thickness of beds recognizable as Madison decreases to as little as 3 feet in the western part of Allamakee County. Thicknesses, though consistently lower, seem quite 
variable in this region, and one of two alternatives is possible. The first is that the Madison is thinning westward, perhaps by pinching out and perhaps by erosion in this area. The second alternative is that the lower portion of the Madison changes in character westward, becoming identical with the underlying Jordan sands, thus making the placing of a contact between the two very difficult. The latter alternative is believed by the writer to be preferable for the following reasons: 1 . The Madison-Oneota contact, everywhere gradational, is still present in the same appearance and relationship as seen in the northeastern part of the county. 2. The Jordan contact, comparatively definite and easily placed in the northeastern part of the county is, in the western part, the subject of considerable question wherever drawn. 3. Exposures have been found in the transition area showing the sands of the lower portion of the Madison becoming progressively coarser westward:

Accompanying the decrease in thickness of recognizable Madison beds westward from the Mississippi River, the n:ember likewise undergoes a considerable change in character. In the western equivalent of the Madison, there are no green shale partings and no conglomerates. Sandstones are medium to coarse in grain size and may, as is the case in exposure 70 (see p. 411), show. considerable regrowth of sand grains, giving an exposure a sparkling appearance in the sunlight. Bedding becomes more massive and dolomite cementation decreases. The transition from Madison to Oneota through a series of alternáting sandy dolomites, dolomitic sandstones and thin sandstone stringers is, however, preserved.

Southward from the northeastern part of Allamakee County, the Madison increases in complexity, bedding is more diversified, green shale seams and partings are more common and conglomerates more numerous. There appears to be a tendency in the southernmost part of the area toward an increase in grain size of the lower part of the section, but green shale'zones and conglomerates clearly mark the base of the Madison.

As more and more sections "were studied it became apparent that no single "marker" bed could be found. Occasionally one horizon could be traced for 1 or 2 miles but could not be identified over any considerable area. Beds changed in character radically within the space of a single outcrop, and it was concluded that only the more general characteristics such as thin bedding, fine- 
ness of grain, and type and degree of cementation are common to the entire area studied.

\section{Cambro-Ordovician Boundary}

Since the Cambro-Ordovician line in Iowa is entirely transitional, it becomes necessary, more or less arbitrarily to select an horizon identifiable over a considerable area. After several sections had been described in detail, and considerable reconnaissance work had been done in several parts of the area, such an horizon was selected and was found to work surprisingly well throughout the area.

In general, the lower portion of the Oneota is characterized by a diversity of lithology. Sandy dolomites and dolomitic sandstones with occasional bands of clean, unconsolidated sandstone are the normal lithology. Sandstones were found, in general, to be more coarsely grained and more poorly sorted than those of the underlying Madison sandstones. Highly oolitic beds and some sparsely glauconitic zones are also common. In some exposures, Cryptozoon reefs occur from 5 to 10 feet above the base. These, however, are found only in a limited number of cases and are therefore of little value in establishing boundaries. Since beds of a transition zone are subject to lateral variation, it is not to be expected that a single bed or a single characteristic can be used for reference successfully over any considerable area. Rather, each contact must be judged individually, and to this end a set of criteria for Oneota and Madison beds were formulated as follows: 1. Unless very clearly unadvisable, the boundary was placed below the lowest good dolomite or sandy dolomite. This rule was violated not more than twice in the 147 exposures studied. 2. Oolitic and glauconitic beds were invariably considered as belonging to the Oneota. 3. Cryptozoon beds were rather loosely considered to be 5 to 10 feet above the base of the Oneota. 4. Strongly dolomite-cemented sandstones with blocky fracture were usually considered as Ordovician unless cross laminated, in which case they were placed in the Madison.

Usually not one criterion but a combination of several were used in placing the boundary, and the reliability of the contact thus selected is shown by the uniformity of the thickness of the Madison throughout the entire eastern half of Allamakee County. 


\section{STRUCTURE}

During the course of field study, a series of altimeter traverses were run throughout the area. Leviels were run from these traverses to all described sections so that elevations are available for nearly all exposures. These elevations, plotted as a structure-contour map on the Cambro-Ordovician contact (see pl. 1), reveal a surprising amount of structure for such a limited area on sediments believed to be, for the most part, undisturbed. A study of plate 1 shows four distinct structural highs trending approximately northwest-southeast. Of these, the southeasternmost is the highest with a relief of 120 feet. The second, in the northeast corner of Allamakee County, is 80 feet high. Because of the irregular distribution of exposures which were restricted to stream valleys, there occur certain areas where control is insufficient. Contours in these areas have been drawn in as dashed lines, in what appeared to be the most logical interpretation on the basis of the facts available. Because of the irregular nature of the distribution of points, more than one interpretation is possible for some localities, and the map is presented as tentative and subject to correction and revision as information increases.

\section{LABORATORY STUDIES}

Technique

During the course of field work, important sections were sampled by channeling methods, and the samples were further studied in the laboratory. Over 500 samples were collected and studied. Individual samples were taken from each unit unless the unit exceeded 5 feet in thickness, in which case it was divided into uniform 5-foot channel samples.

Experimentation showed that coarse crushing provided insufficient surface area to remove rapidly the comparatively insoluble dolomite so that fine crushing was found to be necessary to facilitate the removal of carbonates. To this end, all samples were passed through a series of crushers consisting of a jaw crusher, a set of rolls, and a disc crusher in the order named. All samples were crushed approximately to the size of the largest grains since the nature of the dolomite permitted crushing to this size without undue crushing of quartz grains. The sample was then split on a sample splitter to approximately 100-150 grams. Following this, samples were covered with water and concentrated commercial 
hydrochloric acid was added as rapidly as possible without undue effervescence and foaming until the reaction was complete. This commonily took from two to four hours and an additional two hours was allowed to remove the last traces of dolomite. After samples had been permitted to settle until the supernatant liquid was clear, the acid was drawn off by means of a suction pump and the beakers were filled with clear water and permitted to settle again. This flushing action was repeated six times after which nearly all soluble matter' and acid had been removed from the sample. "Samples were then' dried and reweighed to obtain the loss of weight, that is the weight of soluble material present in the original sample. Each sample was then run through a set of screens selected to correspond with Wentworth's size grade scale.40 All samples were shaken for 20 minutes in a mechanical shaker and then each" individual fraction was weighed to determine relative percentage of the several size grades.

Results were plotted as bar graphs on the basis of the weight of the original sample. That is, the percentage of soluble matter was plotted on the left side as a portion of the total. These bar graphs were plotted one above the other in the form of a geological column for each exposure so that cross sections showing lateral and vertical changes in grade size could be constructed. Two such cross sections were máde, one showing lateral changes westward from the Mississippi River along the Upper Iowa River to the west edge of Allamakee County (see pl.4), and the other showing variations southward from the northeastern corner of the county south to McGregor in northeastern Clayton County (pl. 5).

\section{Biscusgion}

The purpose of mechanical analyses of these sandstones was twofold; first, to see if by mechanical analysis studies a set of criteria could be obtained which would be of value in correlating small isolated exposures showing no contacts; 'and secondly, to bring out more clearly the transitional nature of contacts within the Cambrian and the approximate size ranges of each member.

The Victory section, located in Wisconsin across the Mississippi River from New Albin, Iowa and described by Twenhofel, Raasch and Thwaites ${ }^{41}$ in 1935, has been included in both cross sections

\footnotetext{
${ }^{40}$ Wentworth, C. K., Methods of mechanical analysis of sediments: Iowa Univ. Studies in Nat. History, vol. 11, no, 11, p. 24, 1926.

H. Raseh, G. O., and Thwaites, F: T., Cambrian strata of Wisconsin: Geol. Soc. America Bull.; vol. 46; p. 1690, . 1935.
} 


\section{CROSS SECTION \\ SHOWING}

INSOLUBLE RESIDUES AND MECHANICAL ANALYSES

EXPOSURE NO. 106

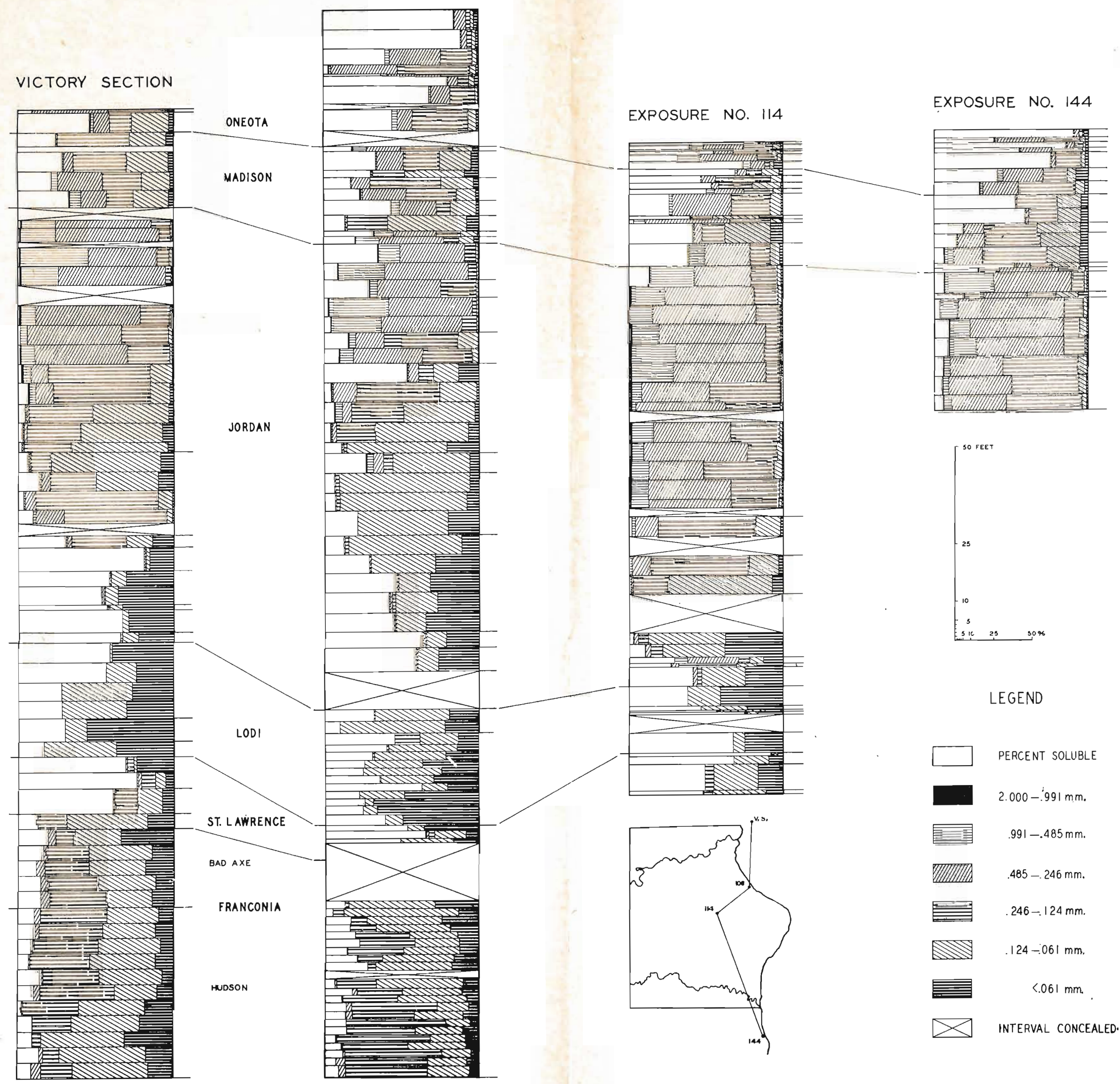




\section{CROSS SECTION \\ SHOWING \\ INSOLUBLE RESIDUES AND MECHANICAL ANALYSES}

EXPOSURE NO. 38
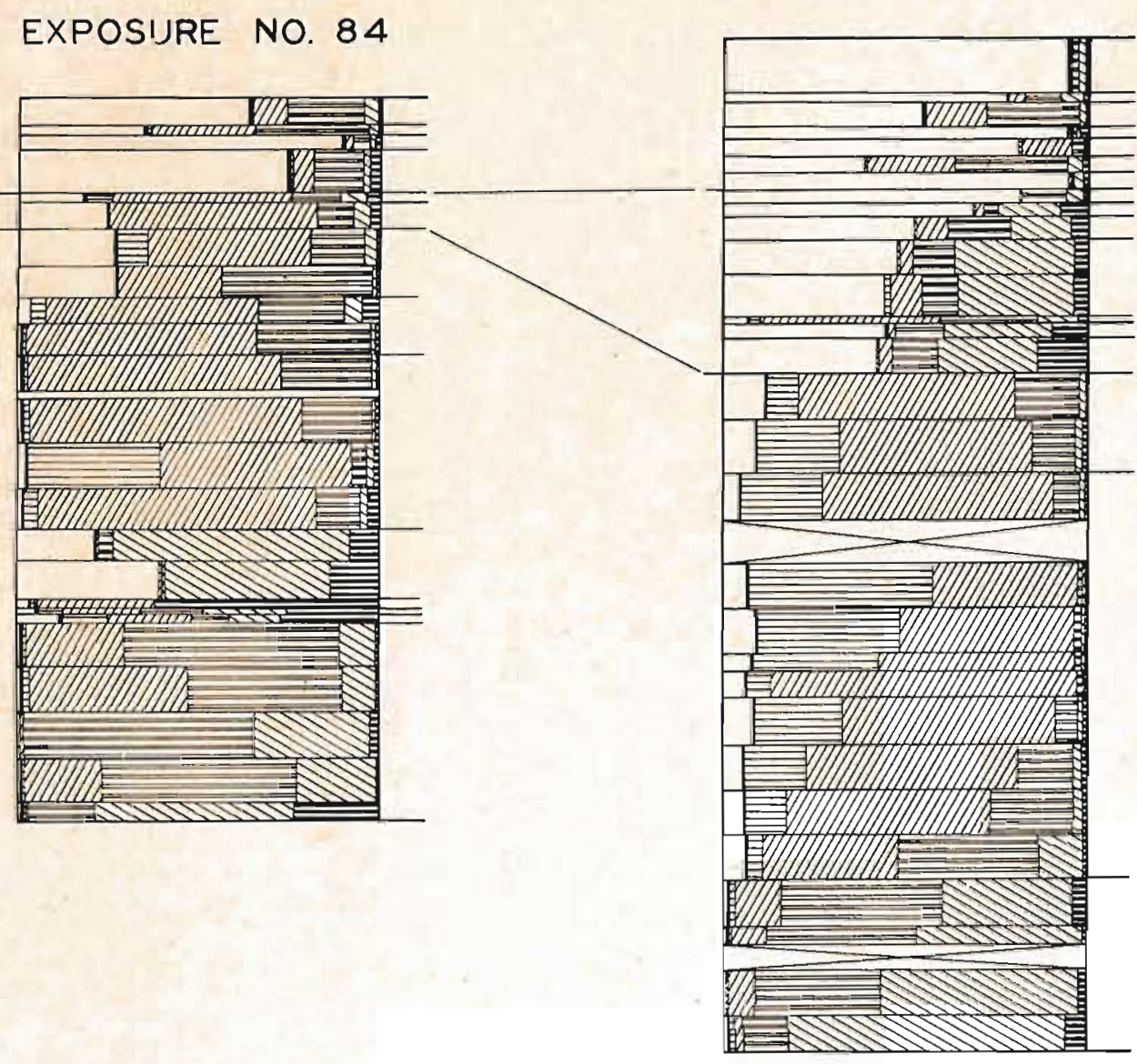

EXPOSURE NO. 70

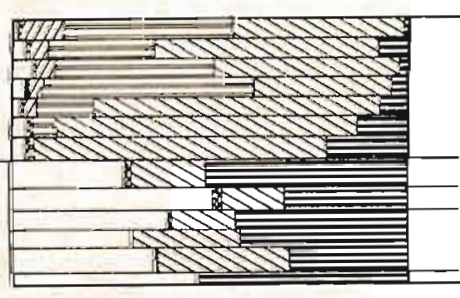

EXPOSURE NO. 89

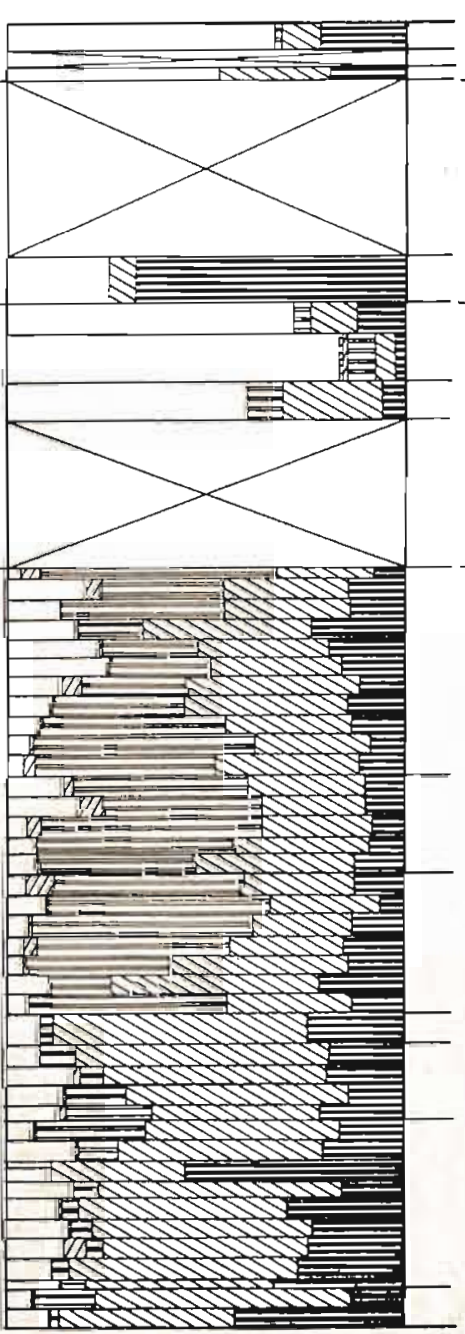

EXPOSURE NO. 92
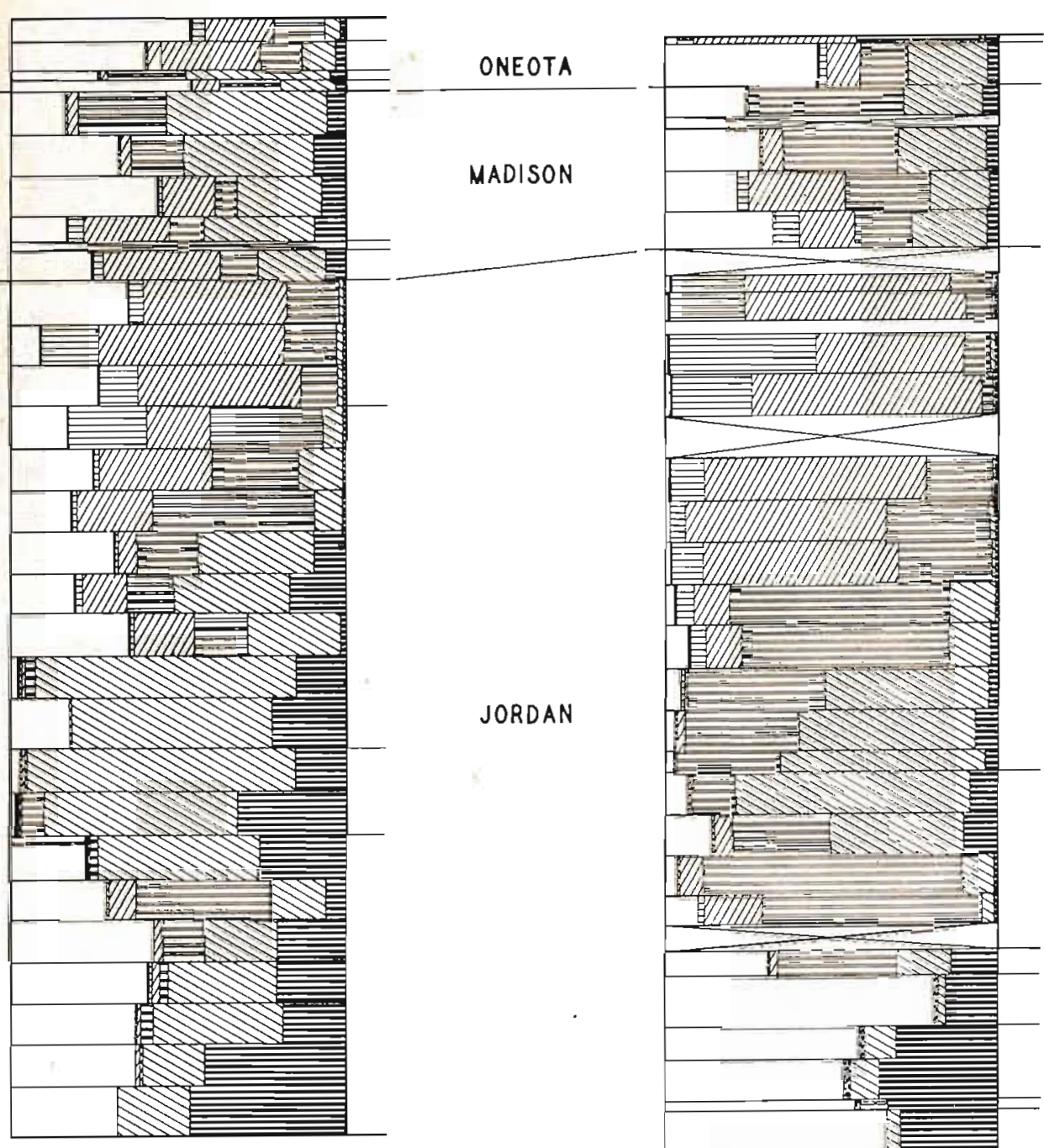

LODI

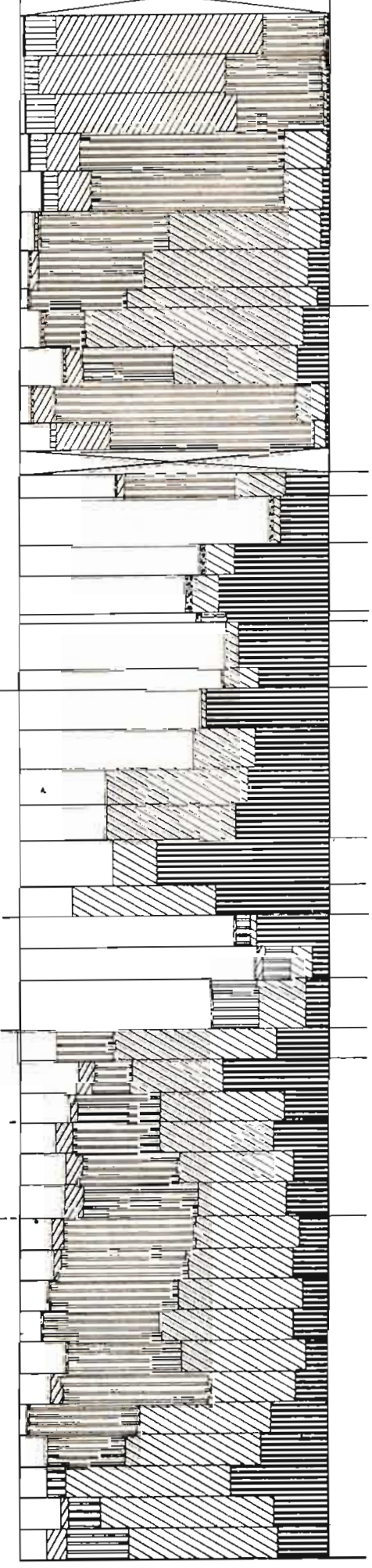

ए PERCENT SOLUBLE

$2.000-.991 \mathrm{~mm}$

E. $.991-.485 \mathrm{~mm}$

VIIIIIIIII

衰

N

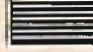

$<.061 \mathrm{~mm}$.

$\sum$ INTERIAL CONCEALED

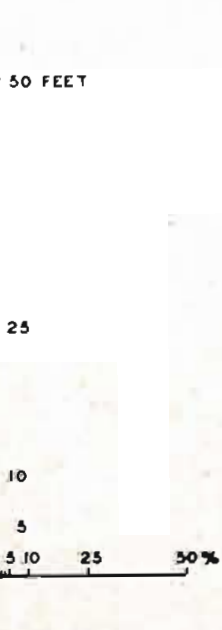


as an "anchor section," since it is both long and very nearly complete.

A study of plates 4 and 5 reveals a number of interesting characteristics of each member. The Franconia formation is characterized by its uniformity throughout, running 70-80 percent fine to very fine sand, with $10-20$ percent silt, $10-15$ percent dolomite, and 1-5 percent medium sand. There appears to be no change whatever in grain size or percentage of dolomitization from Hudson to Bad Axe in the Victory exposure which, in this case, has been drawn almost entirely on paleontologic evidence. Passage from the Franconia to the St. Lawrence is marked by a considerable increase in the percentage of dolomite present, the latter being 60-80 percent soluble. Near the middle of each exposure of the St. Lawrence, a horizon was found which contained 1-2 percent of coarse sand. Otherwise only fine sands to silts are present in addition to the soluble material. Passage upward into the Lodi is marked by a slight decrease in dolomitization, but primarily by a definite and appreciable increase in silt percentage. In general the member averages 30 percent dolomite, $30-40$ percent silt and 20-30 percent very fine sand.

Of the formations and members of the Cambrian the Jordan is the thickest and most varied. The member consists in the lower 25-35 feet of over 50 percent dolomite, $40-45$ percent silt and only 1-5 percent fine and very fine sand. Above this a very regular gradation may, be traced from very fine sand below to medium to coarse sand at the top. This gradation is best shown by exposure 38 (pl. 4), but may be identified in each of the sections shown. The upper portion of the Jordan is further characterized by almost complete lack of dolomite cement though in some sections the presence of dolomite-cemented ledges and sand-calcite nodules belies this statement. Only in the Van Oser beds of the Jordan is there any appreciable coarse and very coarse sand. The JordanMadison contact is marked by a well-defined change in grain size, from predominantly medium grading to coarse below, to more or less equally distributed fine-medium, fine and very fine sand with coarse sand distinctly subordinate, and a marked increase in dolomitization. The contact between the Madison and Oneota is much less well defined as is the case in field studies. There is a gradual increase in the amount of dolomitization and a marked increase in the percentage of medium-grained sand at the expense of fineto very fine-grained sandstone. 
The writer wishes to emphasize again the statement that the greatest value of these plates lies in clearly showing the gradational nature of changes in grain size and the gradational nature of formational and member boundaries in the Cambrian. 


\section{APPENDIX}

\section{Geologic Sections \\ Exposure 38}

Location: Extreme NE1/4 SW $1 / 4$ NW $^{1 / 4}$ sec. 31, T. 100 N., R. 4 W. Exposure on west face of isolated knob immediately northeast of bridge in sec. 31 .

Ordovician system

Feet

Oneota formation

15. Dolomite, light buff, highly coarse sandy to sandstone, finegrained, very dolomitic. Unit is hard and compact.

14. Dolomite, light gray subcrystalline, very hard, with small Cryptozoon structiures throughout

13. Dolomite, drab, finely crystalline, sandy, green-flecked, hard...-.

12. Sandstone, brown, medium-grained, dolomite-cemented; with slight development of nodular surface characterized by presence of sandcalcite concentrations

11. Dolomite, light drab, very finely crystalline, compact to porous

Cambrian system

Trempealeau formation

Madison sandstone member:

10. Sandstone, brown, very dolomitic, firm

9. Sandstone, buff to light brown, very fine-grained, hard, with sharp angular-weathering fragments

8. Sandstone, light drab, very dolomitic and grading to dolomite, very sandy, poorly sorted, very hard.

7. Sandstone, pale buff, fine-grained, unconsolidated, well-sorted, friable, thin-bedded. Lower 4.5 feet show dolomitization along bedding planes and lateral gradation into thinly interlaminated sandstone and siltstone

6. Sandstone, buff, coarse-grained, well-sorted; conglomeratic with thin flat pebbles. (section transferred to south half of bluff)

5. Sandstone, light brown, very fine-grained, well-sorted; innumerable worm borings, very irregular appearance.

4. Sandstone, buff, fine- to very fine-grained with thinly interlaminated bands of siltstone or sshale and 2 to 3 inch bands pinkish dolomite-cemented sandstone. Numerous. worm borings. Numerous shale seams in lower 1 foot

Jordan sandstone member:

3. Sandstone, buff to light buff, irregularly interbanded, mediumgrained, unconsolidated, subangular sandstone and coarse grained, subround, well-frosted, strongly calcite-cemented sandstone. Slight local development of nodular weathering surface 11.0

2. Sandstone, buff, coarse-grained, well-sorted, unconsolidated ex-

1. Sandstone, white to very light buff, fine- to very fine-grained, unconsolidated, friable

Base of section is 806 feet above sea level.

\section{Exposure 70}

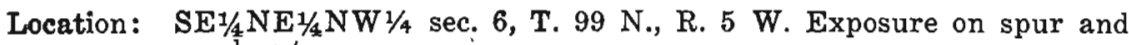
road cut.

Ordovician system

Oneota formation

14. Dolomite, light drab, medium crystalline, hard, numerous cavities 13.0 
13. Dolomite, sandy grading in part to dolomitic sandstone, light drab, fine to coarse sandy, poorly sorted, hard, in beds 8 to 16 inches thick. Lower 5 feet is yery highly sandy.

Cambrian system

Trempealeau formation

Madison sandstone member:

12. Sandstone, - light buff, medium to coarse-grained, interbedded angular coarse-grained sandstone and well-rounded and :frosted sandstone; calcite-cemented and very ledgy in appearance.

Jordan sandstone member:

11. Sandstone, light buff, coarse-grained, fair sorting, strongly caleitecemented, ledgy. Sand-calcite concretions common lodally: $\mathrm{k}$.h. 23.0

10. Sandstone, light buffilfine-grained, very - well sorted, somewhat cross-laminated and with well developed horizontal fine banding. Occasional stringers coarse-garained sandstone with accompanying sand-calcite concretions... Unit-grades to medium-grained at top 24.0

9. Concealed

8. Sandstone, pale buff, fine- to coarse-grained, poorly sorted, strongly calcite-cemented; ledgy

7. Sandstone, very pale buff, fine-grained, very well sorted, uncon-

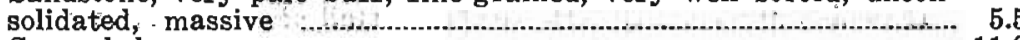

6. Concealed

5. Sandstone, white to buff, fine-grained, very well sorted, entirely unconsolidated except for numerous sand-calcite concretions, horizontally bedded, cross-laminated in parts, occasional green bands in upper part becoming more numerous with depth. Unit becomes more thin-bedded with depth

Lodi siltsone member:

4. - "Siltstone," buff, coarse-grained, soft, thinly-bedded, massive.

3. Siltstone, buff, coarse-grained, thinly bedded, strongly calcitecemented

2. Siltstone buff, very fine-grained, very thin-bedded with well developed shaly appearance and occasional thin dolomitized bands. Innumerable green shale partings throughout.

1. Siltstone, bluish-gray, weathering to buff, very fine-grained, subconchoidal fracture..

Base of section is 687 feet above sea level.

\section{Exposure 84}

Location: NE 1/4 SE 1/4 SE 1/4 sec. 6, T. 99 N., R. 5 W. Exposure in bed of ravine approximately 900 yards west along the south side of Upper Iowa River. Valley from point where north-south town road climbs out of valley.

Ordovician system

Oneota formation

15. Dolomite, drab to light drab, medium to finely crystalline, hard 10.0

14. Dolomite, buff, very sandy to sandstone, very dolomitic, oolitic in parts; sand is medium- to coarse-grained

13. Sandstone; light buff, medium- to fine-grained, well-sorted, angular anconsolidated

12. Dolomite, light drab, medium crystalline, composed of euhedral crystals, porous, hard, very irregular structure................ 11. Dolomite, drab to light drab, hard, medium crystalline, slightly
sandy, blocky fracture; becoming strongly sandy at base........... 4.5

Cambrian system

Trempealeau formation

Madison sandstone member:

10. Sandstone, buff, medium- to coarse-grained, soft, numerous green shale or siltstone bands 
9. - Sandstone, buff, medium- to coarse-grained, fair sorting, occasional to numerous large masses of fine crystalline quartz

Jordan sandstone member:

8. Sandstone, buff to light brown, coarse- to very fine-grained, poorly sorted with interstices filled with silt, unit-very strongly' calcitecemented and ledgy 6 feet from top. Numerous sand-calcite concretions in parts.

7. Sandstone, buff to light brown medium-grained, fairly well sorted, unconsolidated, ledgy, in beds 1 to 3 feet thick with buff-weathered,

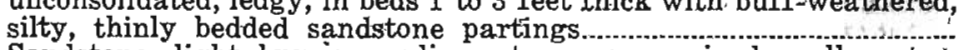

6. Sandstone, light brown, medium - to ccoarse-grained, well sorted, unconsolidated. Large scale cross lamination.................

5. Sandstone, buff, fine-grained, well-sorted, very thinly horizontally

4. Siltstone, olive buff, very thinly laminated, plastic when moist....

3. Sandstone, brown, fine-grained with sprinkling of coarse, very

2. Conglomerate zone, large boulders ( 1 to 2 feet diameter) of coarse-grained sandstone strongly cemented by calcite, in matrix of coarse unconsolidated sand.

1. Sandstone, light brow $n$; fine-grained, well-sorted, unconsolidated, massive. Numerous worm borings in some beds:..........................

Base of section is 737 feet above sea level.

\section{Exposure 88}

Location: North center SE1/4 SE1/4 sec. 6, T. 99 N., R. 4 W. Exposure in west. wall of main valley approximately two-thirds of a mile southeast along valley from mouth.

Cambrian system

Feet

Trempealeau formation

Jordan sandstone member (?):

8. Dolomite, buff, or siltstone, hard, in massive beds at base becoming thin-bedded in upper $1 \frac{11}{2}$ feet

Lodi siltstone member:

7. Siltstone, buff, fine-textured, very thin-bedded, poorly exposed

6. Siltstone to shale, light buff to dark olive green, very thin-bedded with very irregular fracture, soft.

St. Lawrence dolomite nember:

5. Sandstone and siltstone interbanded, light buff, thin-bedded, occasional highly glauconitic bañds; dolomite-cemented, weathering to resistant ledge.

4. Greensand conglomerate, matrix fine- to medium-grained sandstone; pebbles buff, fine-grained sandśtone.

3. DoIomite, drab to pinkish, medium crystalline, highly glauconitic throughout, hard, weathers to slabs, 1 to 3 inches thick:

2. Sandstone, brown, fine-grained, well-sorted, moderately glauconitic throughout, weathers to massive ledge with 1 to 2 inch bedding planes, dolomite-cemented, hard.

Franconia formation:

1. Sandstone, light buff, fine-grained, angular, well-sorted, glauconitic throughout, very thin-bedded, unconsolidated and highly glauconitic in upper 5 feet. Occasional' thin 'dolomite-cemented bands. Greensand conglomerate 3 feet above base.

Base of exposure is approximately 665 feet above sea level, determined from topographic map. 


\section{Exposure 89}

Location: Center NW1/4 SW 1/4 sec. 32 , T. 100 N., R. 4 W. Exposures on crest of knob directly north of school house, on west slope of knob, in road cut on west slope of $\mathrm{knob}$, and in stream bank across creek from knob.

Cambrian system

Trempealeau formation

Jordan sandstone member:

15. Siltstone or fine-textured dolomite, buff, homogeneous, in slabby beds 1 to 3 inches thick

Feet

14. Concealed

13. Sandstone, light buff, fine-grained, silty, mottled, dolomite-cemented and ledgy.

Lodi siltstone member

12. Concealed

11. Siltstone, buff, homogeneous, very thin-bedded. Traces of gray, nonfissile siltstone in lower 3 feet. Exposed only as rubble on slope

St. Lawrence dolomite member:

10. Dolomite, buff to pinkish buff, green-speckled with glauconite, -medium crystalline, sandy, hard, in slabs. 2 to 3 inches thick.

9. Sandstone, buff, fine-grained, well-sorted, in parts strongly mottled with buff siltstone, strongly cemented

8. Concealed

Franconia formation

Bad Axe member:

7. Sañdstóne, light buff to greenish, fine-grained, well-sorted, moderately glauconitic with occasional highly glauconitic bands, unconsolidated at base but becomes bedded and blocky in upper two-thirds

6. Sandstone, dark green and light buff interlaminated, fine-grained, well-sorted, occasional thin-bedded buff siltstone beds in upper part. Some bands dark red from iron cementation

Hudson member (?):

5. Sandstone, shaly, dark gray to green strongly mottled with light gray, very fine-grained, highly glauconitic, soft, very thin-bedded. Mottlings are of light gray siltstone or shale. Two bands buff, fine-grained sandstone to siltstone, thin-bedded, slabby, hard, with gray siltstone partings; one 1.5 feet thick and 1.3 feet above base, second is 6.2 feet above base and 1.8 feet thick: Lower band carries one 1/2 inch bighly fossiliferous zone (Prosaukia misa faunule and Ptychaspis faunule No. 5)

4. Sandstone, buff, fine-grained grading to siltstone in upper part, hard, thin-bedded

3. Siltstone, gray, micaceous, thinly interlaminated with dark green glauconite bands and buff, fine-grained, glauconitic sandstone bands. Color dark gray to green.

2. Sandstone, very fine-grained, buff, and siltstone, very thin-bedded, shaly, interbedded. Slightly cemented, slightly blocky fracture in parts. Numerous bands greensand.

1. Sandstone, very fine-grained with numerous slate gray shale partings giving unit gray - to bluish-gray color, very thin-bedded...

Base of exposure is 650 feet above sea level.

\section{Exposure 92}

Location: - West center SE1/4SE1/4 sec. 15, T. 100 N., R. 4 W. Exposure on first prominent knob south of Upper Iowa River and west of Mississippi River.

Ordovician system

Feet

Oneota formation

19. Dolomite, drab, medium to finely crystalline, hard, coarse sandy and oolitic at base 
18. Sandstone, buff, medium- to coarse-grained, fair sorting, strongly cemented

17. Concealed

16. Sandstone, buff, medium- to coarse-grained, fair sorting, strongly cemented (possibly not in place)
Sandstone, buff, fine- to coarse-grained, poorly sorted, unconsolidated, massive

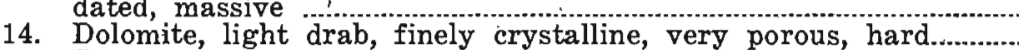

13. Sandstone, buff, fine- to coarse-grained, poorly sorted, very strongly cemented and grading locally into dolomite

12. Sandstone, buff, coarse-grained, very strongly dolomite-cemented

11. Sandstone, light buff, fine-grained, well-sorted, unconsolidated, massive, weathers gray on surface.

10. Sandstone, buff, fine- to coarse-grained, strongly dolomitecemented.

Cambrian system

Trempealau formation

Madison sandstone member:

9. Sandstone, vert light buff, fine-grained, well-sorted, slightly. conglomeratic in upper 1 foot and again in bottom 1 foot, massive; unconsolidated in upper 4 feet and again near base. Central portion consists of thin silghtly cemented beds with cementation concentrated along bedding planes. Cross lamination prominent.... 18.0

8. Sandstone, white, fine-grained, similar to overlying unit but unconsolidated

7. Sandstone, very pale buff, fine- to coarse-grained, poorly sorted, calcite-cemented and with strong development of sand-calcite concretions on weathered surface. Conglomeratic in lower part concretions on weathered
Jordan sandstone member:

6. Sandstone, buff, medium- to coarse-grained, moderately to poorly sorted, unconsolidated but with considerable interstitial dolomite, slightly conglomeratic

5. Sandstone, light buff, fine-grained, well-sorted, unconsolidated.... 41.0

4. Sandstone, very pale buff, fine-grained, unconsolidated, massive,

3. Sandstone, buff, fine-grained, strongly dolomite-cemented, ledgy, rather thin-bedded and only slightly cemented in lower two-thirds, worm borings abundant. Zone of flattened cylinders at top......... 36.0

2. Concealed

Franconia formation:

1. Sandstone, light buff, fine-grained, well-sorted, angular, moderately glauconitic throughout, unconsolidated, in beds 1 to 2 feet
thick with 2- to 5-inch bands of dark green, highly glauconitic sandstone between. Beds weather to finely mottled appearance....

Base of exposure is 698 feet above sea level.

\section{Exposure 106}

Location: SW1/4 SW1/4SE1/4 sec. 29 , T. 99 N., R. 3 W. Exposure on southtrending spur of Mt. Hosmer directly north and adjacent to
Lansing, Iowa.

Ordovician system

Feet

Oneota formation

28. Sandstone, buff to white, medium- to coarse-grained, poorly sorted, strongly dolomite-cemented, irregularly fractured ánd very ircoarse, very dolomitic sandstone to very sandy dolomite 
Cambrian system

Trempealeau formation

Madison sandstone member:

27. Sandștone, gray, medium-grained, fair sorting, slightly dolomitecemented, hard

26. Sandstone, very light buff, fine-grained; well-sorted, slightly dolomitic, firm, thin-bedded.

25. Sandstone, very light buff, medium- to coarse-grained, fair sorting, occasional worm holes, somewhat pebbly, partially cemented, massive

24. Sandstone, light buff, fine-grained, well-sorted, thin-bedded, crossbedding prominent, very . strongly dolomite-cemented .......................

23. Sandstone, white, fine-grained, very well-sorted, unconsolidated, weathered gray. on surface.

22. Sandstone, light brownish buff, similar to underlying unit but strongly dolomite-cemented, hard.

21. Sandstone, light buff, medium- to very coarse-grained, poorly sorted, unconsolidated, conglomeratic with thin flat flakes, slightly shaly in lower part.

Jordan sandstone member (Exposed in road cut below Strong's Point)

20. Sandstone, light buff, medium- ts coatse-grained, fairly well sorted, grading down within $1 \frac{1}{2}$ feet to light buff, coarse-grained,

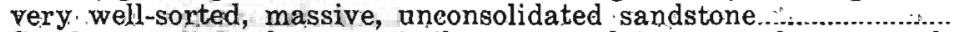

19. Sandstone, light brown, similar to overlying unit but strongly calcite-cemented

18. Concealed

17. Sandstone, light buff, coarse-grained, well-sorted, massive and unconsolidated except for occasional strongly calcite-eemented ledges

16. Sandstone, buff, coarse- to fine-grained, poorly sorted, slightly dolomitic but unconsolidated; transitional to finer beds below.....

15. Sandstone, light buff, medium-grained at top, grading rapidly to fine-grained, very well sorted, unconsolidated.

14. Sandstone, light buff, fine-grained, very well-sorted, similar to overlying unit but strongly dolomite-eemented, in blocky beds 4 to 12 inches thick. Strongly conglomeratic in upper 1 foot.

13. Sandstone, light buff, very fine-grained, similar to overlying unit

12. Sandstone, light buff, very : fine-grained, very. well-sorted, dol omite-cemented, firm, massive beds at top grading to thin-bedded and more dolomitic toward base. Beds $1 / 2$ to 3 inches thick at base 25.0

11. Sandstone, light buff, very fine-grained, very well-sorted, strongly brown mottled with dolomite, thin-bedded, hard........ sorted, firm, unconsolidated, thin-bedded...................................... 9. Concealed (To top of Fire Bell Hill exposure)

\section{Exposure 106 Continued \\ Fire Bell Hill Exposure}

Location: SW $1 / 4$ NE1/4SE $1 / 4$ sec. 29, T. 99 N., R. 3 W. Exposure in Lansing, Iowa, on south end of Fire Bell Hill facing south on the alley north of Main Street qne-half block west from Second Street.

Lodi siltstone member:

8. Sandstone, light buff, very fine-grained, very well-sorted, firmly dolomite-cemented at surface becoming unconsolidated within. Weathered massive

7. Sandstone, light buff, very fine-grained, and siltstone; unit consists of thinly interlaminated dolomite-cemented and uncemented bands; conglomerate zone 5 feet below the top. 
6. Gonglomerate, a reworked zone consisting :of angular to rounded siltstone pebbles in a highly contorted matrix of similar ma-

terial; strongly dolomite-cemented in parts.
Sandstone, buff, olive in fresh fragments, yery fine-grained sandstone to siltstone, yery thinly bedded weathering to shaly appearance on weathered surface, siltstone predominant in lower twothirds

St. Lawrence dolomite member:

4. Sandstone, buff, and siltstone, similar to overlying unit but dolomite-cemented and ledgy. Two conglomerate zones near the middle

3. Sandstone to dolomite, glauconitic, hard, sandstone, fine-grained, well-sorted,: strongly dolomite-cemented and grading to dolomite in part, conglomeratic.

Concealed

Franconia formation

Bad Axe and Hudson sandstone members:

1. Sandstone, light buff, fine-grained, very thin-bedded, slightly cemented, moderately glauconitic throughout and with occasional highly glauconitic zones.

Base of exposure is 670 feet above sea level.

\section{Exposure 114}

Location: NE1/4 \& SW $1 / 4$ SE $1 / 4$ NE $1 / 4$ sec. 20 , T. 98 N., R. 4 W. Two exposures, the upper located in a ravine back of the farm, on west side of road, and the lower in road cut on west side of road immediately north of farm buildings.

Ordovician system

Feet

Oneota formation

33. Dolomite, yellowish buff, finely crystalline, medium to coarse

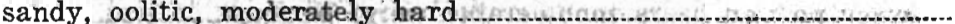

32. Sandstone, buff, medium- and coarse-grained, fairly well-sorted, dolomitic but weak and friable, grading to white at base

31. Dolomite, buff to light greenish, subcrystalline, fine to coarse,

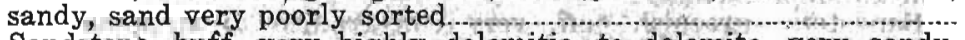

30. Sandstone, buff, very highly dolomitic, to dolomite, very sandy,

29. Sand fine-grained, very well-sorted. dolomitic but weathered to weak friable condition, sand fairly well-sorted

28. Dolomite, buff to pinkish, finely crystalline, moderately hard, fine to coarse sandy, conglomeratic.

27. Dolomite, bluish gray, very finely crystalline, very hard, subconchoidal fracture in places, numerous cavities, unit grades to buff and slightly sandy in lower one half

26. Dolomite, buff to pinkish in parts, fine to coarse sandy, very poor sorting, dense, hard

Cambrian system (?)

Trempealeau formation

Madison sandstone member:

25. Dolomite, very sandy to sandstone, very dolomitic, buff, grading to pinkish gray in center, sand medium- to fine-grained, poorly sorted, hard

24. Sandstone, buff, highly dolomitic with euhedral dolomite crystals, sand medium- to fine-grained, well-sorted.

23. Dolomite, buff, sandy, finely crystalline, sand, fine- to coarsegrained, moderately to poorly sorted. (1) 
21. Sandstone, buff to brown, medium-grained, fairly well-sorted, calcite-cemented in part. Cross lamination and bedding planes weathered into relief where calcite cementation has been concentrated

20. Sandstone, buff,' fine-grained, well-sorted, unconsolidated, with numerous worm borings.

19. Sandstone, white, fine- to coarse-grained, poorly sorted, soft, unconsolidated, as one bed

18. Sandstone, buff and white, fine-grained, well-sorted, in thin interbedded bands of massive uncemented sandstone and blocky calcitecemented sandstone.

17. Sandstone, buff, light brown and white, fine-, medium- or coarsegrained, moderately to poorly sorted. Unit consists of closely spaced calcite-cemented ledges with seams of unconsolidated material between; traces of green shale 3 feet above base.

Jordan sandstone 'member:

16. Sandstone, brown, coarse-grained, well-sorted, subangular to curvilinear, unconsolidated, massive, grading to medium-grained between 30 and 35 feet and becoming ledgy between 50 and 55 feet

15. Sandstone, light buff, fine- to medium-grained, very well-sorted, unconsolidated, massive.

14. Sandstone, light buff to white, fine- to medium-grained, very well-

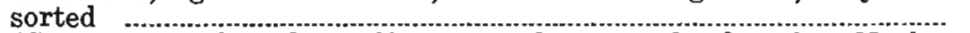
(Section transferred to adjacent road cut north of ravine. No loss of beds.)

13. Sandstone, very light buff to white, fine-grained, very well-sorted, slightly cemented but friable at top; becoming more firm toward the base; worm borings abundant; as heavy massive beds

12. Sandstone, an irregular pockety zone of coarse- to very coarsegrained, variably cemented sandstone and very fine-grained wellsorted. sandstone.

11. Sandstone, light buff to white; fine- to medium-grained, unconsolidated but very thinly laminated with a hard band in the center; lower portion bears innumerable worm borings

10. Sandstone, buff to white mottled, very fine-grained; as heavy massive beds

Lodi siltstone member:

9. Sandstone, greenish buff, very fine-grained to siltstone, thinly interlaminated with thin green shale partings; weathers to thin flat irregular slabs giving a shaly appearance.

8. Sandstone, buff, extremely fine-grained to siltstone, dolomite-cemented, weathering to a prominent bed; numerous small cavities

7. Sandstone, light buff, extremely fine-grained, well-sorted, soft in parts shaly; grading down into.

6. Sandstone, brown to purplish gray, highly irregular in structure, conglomeratic with light buff, thin, flat pebbles and stringers....

5. Concealed

4. Siltstone to extremely fine-grained sandstone, brown to buff, very well-sorted and very homogeneous in character; breaks into flat dolomite-cemented slabs 1 inch to 3 inches thick.

St. Lawrence dolomite member:

3. Dolomite, bluish drab, fine to medium crystalline, moderately glauconitic, becoming highly so in upper 2 inches unit somewhat conglomeratic, hard, contains numerous small cavities.

2. Siltstone or very fine-grained sandstone, buff weathered, slightly glauconitic, slabby in upper 11/2 foot becoming more massive below; green shale partings common in parts.

1. Sandstone, light buff, fine-grained, well-sorted, green-mottled with green shale partings; irregular fracture

Base of exposure is 763 feet above sea level. 


\section{Exposure 139}

Location: West center SW1/4 SE1/4 sec. 10 T. 95 N., R. 3 W. Exposure 0.57 of a mile north along road from bridge at Marquette, and 2.27 miles south along road from road crossing immediately south of bridge across Yellow River. Exposure it found in small sag carved by stream.

\section{Ordovician system}

Oneota formation

17. Dolomite (extending upward in ravine bed)

16. Dolomite, drab to pinkish and buff, finely crystalline, highly sandy; sand coarse- to fine-grained with stringers and pockets of coarse-grained sand.

15. Sandstone, drab to buff, fine-grained, well-sorted, very highly dolomitic, very hard, dense, strong blocky fracture, cross-laminated, in well-defined beds 2 to 6 inches thick.

Cambrian system

Trempealeau formation

Madison sandstone member:

14. Sandstone, buff, medium- to coarse-grained, fair sorting, strongly cemented, blocky , fracture, thick-bedded.

1.3. Sandstone, buff, coarse-grained, poorly sorted, conglomeratic, dolomite-cemented, hard, worm borings common, some crosslamination

12. Sandstone, light buff, coarse-grained in upper 6 inches grading to medium-grained below, well-sorted, cross-laminated with streaks white sand parallel to cross lamination in top 6 to 8 inches.

11. Sandstone, buff, fine- to coarse-grained, poorly sorted, somewhat dolomite-cemented; weathers thin-bedded

10. Sandstone, very light buff to light gray, coarse- to medium-grained, poorly sorted, massive; numerous green shale partings, unconsolidated

9. Sandstone, buff to pinkish, fine- to coarse-grained, poorly sorted strongly dolomite cemented, blocky fracture, in beds 2 to 6 inches thick

8. Sandstone, white, medium- to very coarse-grained, poorly sorted, unconsolidated, massive; innumerable green shale partings........

7. Sandstone, buff, fine- to very coarse-grained, very poorly sorted, conglomeratic, dolomite-cemented, green 'shale partíngs in parts, worm borings common.

6. Sandstone, light buff, medium- to coarse-grained, fairly well-sorted, unconsolidated, massive, friable

5. Sandstone, light buff, fine- to medium-grained - with sprinkling coarse grains, moderately to poorly sorted, dolomite-cemented, worm borings common in upper part.

4. Sandstone, buff, coarse-grained, well-sorted, dolomitic but friable, highly conglomeratic

3. Sandstone, light buff, coarse-grained, well-sorted, unconsolidated, massive; with 2 thin green shale partings at 7 and 14 inches below top

2. Sandstone, buff, coarse-grained, well-sorted, with much interstitial crystalline dolomite, highly conglomeratic in upper part and thinly horizontally bedded in lower portion.

Jordan sandstone member:

1. Sandstone, light buff, coarse-grained, well-sorted, unconsolidated, friable with occasional green shale flakes, massive.

Base of section is 632 feet above sea level. 


\section{Lansing City Well No. 3}

Location: Middle of intersection of Maín and Front Streets, Lansing, Iowa. Elevation: Curb of well is 639 feet above sea level:

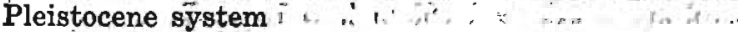

River alluvium

1. Sand, brown, coarse-grained to granules, many abraded dark brown rock fragments.

Feet

Cambrian system

Franconia formation

Goodenough member

2. : Siltstone or shale (well mud), pale green, slightly micaceous........

Irontön member (thickness, selected arbitrarily)

3. Sandstone, 'white, 'coarse-grained; well-sorted, clean........................20t

Dresbach formation

Galesville -member

4. Sandstone, white, coarse-grained, well-sorted, clean...................... 57 t

5. Sandstone, bluish white, coarse- to very coarse-grained, wellfrosted and rounded

Eau Claire member

6. Sandstone, white; very fine-grained, very well-sorted, slightly glauconitic, slightly micaceous.

7. Siltstone to fine-grained sandstone, pale orange

8. Siltstone to fine-grained sandstone, orange.

9. Sandstone, white, very fine-grained, very well-sorted, slightly glauconitic, slightly micaceous................. 16

10. Sandstone, white, coarse-grained, well-sorted, clean

11. Sandstone, white rery fine-grained, very well-sorted, slightly glauconitic, slightly micaceoùs.

Mt: Simon member

12." 'Sandstone, light yellow, coarse-grained, well-sorted, clean..............

13. Sandstone, white, coarse-grained, well-sorted, clean

14. Sandstone, brown, coarse-grained, fair sorting, clay coated:

.

16. Sandstone, brown, coarse-grained, well

17. Sandstone, white, coarse-grained, well-sorted, clean ....................... 15

18. Sandstone, brown, coarse-grained, fair sorting, clay coated............- 7

19. Sandstone, white, coarse-grained, well-sorted, clean ................... 8

20. Sandstone', brown, coarse-grained, well-sorted, clay coated ….... 8

21. Sandstone, very coarse-grained to granules, well-rounded, $99 \%$ quartz sand.

\section{Marquette}

Chicago, Milwaukee, St. Paul and Pacific Railroad Well

Elevation: Curb of well is 628 feet above sea level.

Pleistocene system

River alluvium

1. Silt, buff, clayey, some sand, slightly calcareous.

2. Clay, reddish gray; soft, unctuous, with considerable-sand ............. 10

3. Sand, buff, coarse medium-grained, clayey, with chert and limestone fragments in lower part

Cambrian system

Franconia formation

Goodenough (?) and Hudson members

4. Sandstone, buff, very fine-grained; : well-sorted, slíghtly cemented, silty; with 10-15 percent white chert in upper part. 
5. Concealed

Feet

6. Dolamite; very light buff to light gray, finely crystalline, very

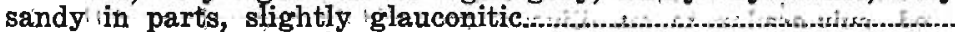

7. Dolomite, light buff, finely erystalline, translucent, .hard, slightly glauconitic

8. Sandstone to shale, light gray, very fine-grained, very silty, glau-

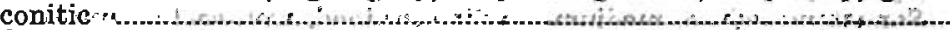

9. Sandstone, greenish gray, silty to clayey, moderately glauconitic

10. Sandstone to shale, light gray, very fine-grained, very silty, glauconitic

11. No sample....................conitic

13. No sample.

Ironton member

14. Sandstone, light buff, medium- to coarse-grained, dolomite-cemented in parts, glauconitic

15. Sandstone, white, coarse- to medium-grained, curvilinear to subround, well-frosted, well-rounded, no glauconite

Dresbach formation

Galesville member

16. Sandstone, white predominantly medium- to coarse-grained, wellsorted, very slightly cemented in upper 10 feet Eau Claire member (?)

17. Sandstone, medium-grained grading to fine, slightly dolomitic, slight traces of shale.

Waukon City Well No. 3

Elevation: Curb of well is 1279 feet above sea level.

Cambrian system

Trempealeau formation

Madison member (top 548 feet below curb)

1. Sandstone, light buff, fine- to coarse-grained, poorly. sorted, subangular to curvilinear, well-frosted, slightly dolomitic in lower part

Jordan member

2. Sandstone, light buff, medium- to coarse-grained, curvilinear to subround, clean

3. No sample.

4. Sandstone, light buff, medium- to coarse-grained, clean

5. Sandstone, light buff to white, medium- to fine-grained clean.......

6. Sandstone, light buff, medium- to coarse-grained, clean.................... Lodi member

7. Sandstone, very fine-grained to siltstone, white, uncemented........

8. Sandstone, medium- to fine-grained, predominantly medium.

St. Lawrence member

9. Dolomite, dark drab gray, medium crystalline, translucent, medium to coarse sandy

Franconia formation

10. Sandstone, light gray, fine-grained, -angular, well-sorted, slightly glauconitic

11. Sandstone, light gray, fine-grained, strongly dolomite-cemented, grading in lower part to 50 percent light brown very finely crystalline dolomite. One thin band brown, translucent, fine to medium crystalline dolomite with large glauconite grains and medium- to coarse-grained sand.

12. Sandstone, very fine-grained, to siltstone, pale green, very clayey, uncemented

13. No sample (Driller's log reports green clayey shale)

14. Sandstone, very fine-grained, to siltstone, pale green, very clayey, uncemented 
Ironton member (?)

15. Sandstone, medium - to coarse-grained, moderately to poorly sorted, subangular to curvilinear, moderately frosted, slightly dolomite-cemented, slightly glauconitic

Dresbach formation (?)

Galesville member (?)

16. Sandstone, white, medium- to fine-grained, well-sorted, uncemented, no glauconite 


\section{INDEX}

A

Abstract, 383

Allamakee County, 391, 395, 397, 400, 401, 402, 403, 404, 405, 406; detailed geologic sections in, appendix

Appendix, 409

Atwater, G. I., cited, 388,389

\section{B}

Bad Axe member, 386, 394; detailed sections of, appendix

Berkey, C. P., cited, 388

Black Earth formation, 390

\section{C}

Calvin, Samuel, cited, 384

Cambrian strata, detailed sections of, 408; distribution of, 391 ; elevation of, 405; generalized section of, 386 ; general statement, 385; laboratory study of, 405; members of, 386 ; nomenclature of, 387; structure of, 405

Cambro-Ordovician boundary, 400 , $401,403,404$.

Clayton County, 402, 406; detailed geologic sections in, appendix.

Conglomerates, in Jordan member, 398; in Madison member, 402

Crystalline rocks, 392

\section{D}

Distribution of Cambrian strata, 391

Dolomitization, 397, 401

Dresbach formation, 385, 386, 388, 390 ; detailed sections of, appendix; lithology of, 391

Driftless Area, 395

\section{$\mathbf{E}$}

Eau Claire member, 386, 388, 389, 390 ; detailed sections of, appendix; lithology of, 392

Eau Claire grits, 387

Eau Claire trilobite bed, 387

Fauna, see Fossils

\section{F}

Fire Bell Hill section at Lansing, 396, 414, plate 1

Fossils, 385, 394, 396

Franconia formation, 385, 386, 388, 389,390 ; detailed sections of, appendix; fossils in, 394; lithology of, 393 , 394; mechanical analyses of 407; subdivisions of, 389

\section{G}

Galesville member, 386, 388, 389, 390, plate 1; detailed sections of, appendix; lithology of, 392, 393

Glauconite, in Franconia formation, 389, 396; in Mazomanie formation, 389 ; in Oneota formation, 404; in Trempealeau formation, 395

Goodenough member, 386, 394

Grout, F. F., cited, 389

\section{$\mathbf{H}$}

Hall, C. W., cited, 388

Hinckley formation, 388, 389

Hudson member, 386, 394; detailed sections of, appendix

Hudson trilobite bed, 387

\section{I}

Irving, R. D., cited, 387

Ironton member, 386,394 , plate 1

\section{$\mathbf{J}$}

Jordan member, $386,387,388,390$, plate 1 ; boundaries of, 399 ; conglomerates in, 398; detailed sections of, appendix; dolomitization of, 397; lithology of; 396 ; mechanical analyses of, 407; Norwalk facies of, $386,389,390,399,407$; sand-calcite nodules in, 392, 398, 407; type locality of, 389; Van Oser facies of, 386, $391,396,397,399,407$

$\mathbf{K}$

Kansas Geological Society classification of the Cambrian, 390, 396 
L

Laboratory studies of Cambrian strata, 405

Lansing, Allamakee County, 391 , plate 1; deep well at, $392,393,418$; Fire Bell Hill section at, 396,403 , plate $i$

Lodi-member, 386, 390; plate 1; detailed sections of, appendix; fossils in, 396; lithology of, 395

\section{M}

Madison member, 386, 387, 388, 392, 400 ; age of, 400 ; conglomerates in, 402; detailed sections of, appendix; dolomitization of, 401 ; lithology of, 400,401 ; sand-calcite nodules in, 402 ; shale partings in, 402

Marquette, Allamakee County, 3̈91; railroad well at; 393,418

Mazomanie formation, 389

McGregor; Clayton County, 401

Mechanical analyses, 406

Mendota formation, 387,388

Mt. Simon member, $386,389,392$; detailed sections of, appendix; lithology of, 391

\section{$\mathbf{N}$}

New Albin, Allamakee County, 391

New Richmond formation, 387

Nicollet Creek formation, 390

Nomenclature of the Cambrian, history of, 387

Norton, W. H., cited, 388, 391, 392

Norwalk facies of Jordan member, $386,389,390,399,407$

\section{0}

Oneota formation, $389,391,404$; detailed sections of, apepndix; lithology of, 404

Outcrops of Cambrian strata, 391

Owen, D. D., cited, 387

$$
\mathbf{P} \text {, . }
$$

Paleontology, see Fossils

Pentland, A, cited, 389

Potsdam sandstone, 387

Pre-Cambrian rocks, 392

\section{$\mathbf{R}$}

Raasch, G. O., cited, 388, 390, 394, 400, 406

Resser, C. E., cited, 389

s

St. Croixan series, 385,386

St. Lawrence member, 386, 387, 388, 389,390 ; detailed sections of, appendix; lithology of, 395

Sand-calcite nodules in Jordan member, 392, 398, 407; in Madison member, 402

Schwartz, G. M., cited, 390

Stauffer, C. R., cited, 389,390

Structure of Cambrian strata, 405

\section{$\mathbf{T}$}

Tester, A. C., cited, 383

Thiel, G. A., cited, 390

Thwaites, F. T., cited, $388,389,390$, 400,406

Trempealeau formation, $385,386,389$, 390 ; detailed section of, appendix; lithology of, 394

Trowbridge, A. C., cited, $388,389,396$

Twenhofel, W. H., cited, $388,390,400$, 406

\section{$\mathbf{U}$}

Ulrich, E. O., cited, $388,389,399,400$

V

Van Oser facies of Jordan member, $386,391,396,397,398,399,407$

Vietory section in Wisconsin, 394, 395, 406,407

\section{W}

Waukon, Iowa, well at, 393,419

Well records at, Waukon, 393, 419; at Lansing, 392, 393, 418; at Mar$x$ quette, 393,418

Wentworth, $C$. $K$, cited 406

Winchell, N. H.; cited, $387,388,398$

Winneshiek ,County, 399

Wisconsin, Victory section, 394, 395, 406, 407

Wooster, L. C., cited, 387, 388 